KS. TADEUSZ FITYCH - WAŁBRZYCH

\title{
WSTĘP DO BADAŃ NAD DIECEZJĄ NOLA W XVII WIEKU
}

Przedmiotem naszej uwagi będzie włoska diecezja Nola, należąca do metropolii Neapolu, a położona w Kampanii. Przybliżając główne nurty jej dziejów oraz podstawową bibliografię usiłujemy dać tu podstawy do całościowych badań nad obrazem życia religijnego i duszpasterstwa pielęgnowanego na obszarze diecezji Nola w wieku XVII. Stąd to mamy nadzieję iż w przyszłości otrzymamy odpowiedzi na między innymi na dwa istotne pytania - czy po trydenckiej reformie in capite, tamtejsi hierarchowie, $\mathrm{z}$ jednej strony bedący jeszcze często nepotami potraktowali objęcie diecezji Nola, jedynie jako moment przejściowy w rozwoju ich kariery kościelnej, czy też mieli już w swej świadomości nowy - potrydencki ideał biskupa i w pełni zaangażowali się w realizację reformy katolickiej? W jakim stopniu i dokonało się jej wcielenie?

Aktualnie na jej obszarze liczącym ok. $450 \mathrm{~km}^{2}$ zamieszkuje tam niespełna 500 tys. ludności (a przy tym ok. 40 tys. w samym mieście biskupim). Ponadto w tzw. sieci trzech 3 stref pastoralnych, która obejmuje łącznie 8 dekanatów i 115 parafii, posługuje 154 księży diecezjalnych, 95 zakonników i 14 stałych diakonów ${ }^{1}$ oraz życia konsekrowanego należące do 10 rodzin zakonnych męskich i 34 żeńskich. Ów Kościół lokalny, na którego czele od roku 1999 stoi biskup Beniamino de Palma (ur. 1941) wywodzący się z rodzinny zakonnej Misjonarzy św. Wincentego a Paulo, wydał w ostatnim czasie czterech biskupów. Diecezja ta posiada aktualnie: niższe i wyższe seminarium duchowne, Studium Teologiczne, Centrum Studiów i dokumentacji św. Paulina z Noli, bibliotekę diecezjalną i redakcje kilku periodyków kulturalno-religijnych.

${ }^{1}$ Zob. Annuario della Conferenza Episcopale Italiana 1999. Diecezja Nola w roku 1985 obejmowała powierzchnię $450 \mathrm{~km}^{2}$, którą zamieszkiwało ok. 520 tys. mieszkańców (w r. 1961: 329.208, w tym ok. 300 tys. katolików). Duchowieństwo tej diecezji, z biskupem diecezjalnym na czele i dwoma biskupami emerytami, liczyło wówczas 167 księży diecezjalnych obsługujących 116 parafii, 99 zakonników zgromadzonych w 24 klasztorach, a duszpasterzujących w 11 parafiach, oraz 557 sióstr zakonnych w 71 klasztorach. Zob. Diocesi di Nola, Annuario della Chiesa di Nola, [Nola] 1985, s. 11; Nola, w: LThK, Bd. 7, 1019. 
Już w starożytności chrześcijańskiej Nola - jedno z najstarszych i najbogatszych miast Kampanii - zasłynęła z tego iż pierwszym jej biskupem ${ }^{2}$ był św. Feliks, a czternastym z kolei i najbardziej znanym jego następcą - św. Paulin z Noli (409-431), rodem z Bordeaux w Akwitanii, co sprawiło że jej nekropolia słynęła bez mała $z$ rangi drugiego Rzymu.

Również w kręgu obywateli średniowiecznego i nowożytnego miasta Nola znajdujemy już cały szereg rodzin nobilitowanych m.in. Abundo, Albertini, Aragona, Balleta, Barone, Caraceiolo, Martinello, Mastrilli, Monforte, Orsini, Rosso, Vitagliano ${ }^{3}$. Natomiast najbardziej znanymi osobistościami Noli byli m.in.: Pomponio de Algerio ( $\uparrow 1556)$ luteranin skazany na śmierć w Rzymie, poeta Transillo, lekarz Santorelli, Giovanni di Nola, filozof Giordano Bruno (1548$-1600)^{4}$, Domenico del Giovane (1510-1592) słynny organista i kompozytor inspirowany miejscowym folklorem 5 . Jak też wybitny architekt militarny Carlo Tetti.

Również i w wieku XVII nie brakowało wybitnych osobistości. W roku 1639 zmarł wybitny nolanin Gianmichele Ruffi, biskup i karmelita, który po szeregu odpowiedzialnych funkcjach na koniec pełnił funkcję prokuratora generalnego swego zakonu. Niespełna dwadzieścia lat później - w roku 1653 w opinii świętości zmarł kolejny mieszkaniec tego miasta, uczony i intelektualista Antonio Santorelli, a z kolei w roku 1655 biskupem Montepeloso został patrycjusz Noli i Rzymu Filippo Cesarino $(† 1683)^{6}$.

Dodajmy iż w latach 1616-1655 w regionie tym działało, albo stąd się wywodziło, wielu wybitnych zakonników takich jak kapucyn Francesco Maffeo (†1616) z Lauro, kolejni dwaj wybitni franciszkanie konwentualni z klasztoru w Noli to Daniele Coco $(\dagger 1623)$ i doktor teologii, wykładowca w Mediolanie, Neapolu i Salerno Bonaventura Passevo (†1629), a przy tym niektórzy z nich zmarli w opinii świętości. W tym kręgu byli ponadto Michele Trabucco, który w roku 1637 przeprowadził tam misje diecezjalne, a następnie w pobliskim Casarano założył

${ }^{2}$ Należy tu zauważyć, że publikacje na ten temat począwszy od Ferdinanda Ughellego nie zawierały jednoznacznie sprecyzowanego katalogu biskupów (jego katalog biskupów liczył do roku 1615 zaledwie 57 hierachów, kiedy najnowsze zestawienie tego typu podaje ich już 73 - zob. F. Ughello, Italia Sacra sive de episcopis Italiae, t. 6, Venetia $1720^{2 \mathrm{~s}}$, s. 242-266, 857). Co więcej, nawet do dzisiaj problem ten nie został w pełni rozwiązany. Poniżej odwołujemy się najnowszych ustaleń dokonanych przez zespół badaczy w Nola, w oparciu o komplksowe konsultacje źródłowe i bibliograficzne. Należy przy tym dodać, iż pierwsi dwaj biskupi odnośnie których istnieją pewne przekazy to San Massimo (95-120) i San Quinto (120-150). Za tym kręgiem badczy z Centrum studiów i dokumentacji n.t. San Paolino di Nola przyjmujemy nową numerację porządkową nolańskich ordynariuszy.

${ }^{3}$ Zob. G. B. Di Montanara, Le famiglie 'egregie' di Nola nel primo decennio del secolo decimosesto, ,Rivista araldica”, 58 (1960), 5, s. 185-190.

${ }^{4}$ Zob. m.in. V. Spampanato, Vita di Giordano Bruno con documenti editi e inediti, Messina 1921, (edizione anasatica con postfazione di N. Ordine, Roma 1988).

${ }^{5}$ Zob. także, A. Capelletti, Guerrieri e mistici in Nola medievale, Nola 1991; F. G. Goffredo, Vita del venerabile P. Marcello Mastrilli della Compagnia di Gesü, Napoli 1910; G. Iannelli, Brevi cenni degli scrittori ed uomini illustri della cittá di Nola e di quelli si occuparono della medesima cittá, Caserta 1888.

${ }^{6}$ Zob. G. Remondini, Della Nolana ecclesiastica storia, t. 3, s. 302-303, 309, 316, 318, 321. 
zgromadzenie księży misjonarzy i wreszcie jezuici Bernardino Scolas i Carlo Carafa, założyciel nowego zgromadzenia?

Ponadto z polskiego punktu widzenia ciekawym jest tu między innymi także fakt, że w roku 1640 król Filip IV sprzedał Władysławowi IV królowi Polski (1632-1648) 16 dominiów wchodzących w skład feudo Nola. Naturalnie i w tym okresie aktualnym pozostawał problem "sum neapolitańskich", tzn. 430.000 dukatów pożyczonych przez królową Bonę królowi hiszpańskiemu Filipowi II, o których zwrot bezskutecznie zabiegał król Zygmunt II August i jego następcy. Dodajmy jeszcze, że to właśnie w diecezji Nola, według opinii Carlo Guadagniego miałby przez pewien okres przebywać (czy też nawet pracować lub zdobywać doświadczenie) audytor polskiej nuncjatury - rzymianin Emilio Altieri (*1590), a przyszły nuncjusz Neapolu w latach 1644-1652 i wreszcie papież Clemente X. W wieku XVII, przez okres aż 40 lat jej biskupem był Giovanni Battista Lancellotti, nuncjusz w Polsce (1622-1627) - (Fotografia 1). Już od roku 1623 Zygmunt III Waza rozpoczął aż ośmioletni bój o jego kardynalat ${ }^{9}$.

Niestety do dzisiaj, nadal odnotowujemy brak monograficznego opracowania zarówno dziejów samej metropolii Neapolu jak i owej prestiżowej diecezji Nola. Co więcej brakuje też literatury na temat tamtejszych zasobów źródłowych, jak i opracowań w zakresie hierarchii, dziejów ustroju i instytucji kościelnych. Ponadto większość publikacji dotyczących miasta i regionu Nola, prawie wyłącznie skupia swą uwagę jedynie na zagadnieniach archeologii chrześcijańskiej, architektury, ubranistyki, sztuki sakralnej, czy też popularnonaukowych opracowaniach historii niektórych budowli sakralnych.

${ }^{7}$ Zob. tamże, s. 293, 298, 300-302 i 311.

${ }^{8}$ Zob. T. Fitych, Krag rodzinny Giovanniego Battisty Lancellottiego, 31-szego nuncjusza apostolskiego w Polsce, „Roczniki Teologiczne”, 47 (2000) z. 4, s. 81-112, tenże, Kariera kurialna i dyplomatyczna do roku 1614 Giovanniego Battisty Lancellottiego nuncjusza apostolskiego w Polsce w latach 1622-1627, w: Stowo nieskowane, Księga Jubileuszowa dla ks. Jana Kruciny, red. A. Nowicki, J. Tyrawa, Wrocław 1998, s. 661-672.

${ }^{9}$ Zob. T. Fitych, Rekomendacje Zygmunta III Wazy w sprawie kardynalatu Giovanniego Battisty Lancellottiego nuncjusza apostolskiego w Polsce w latach 1622-1627, „Nasza Przeszłość”, 91 (1999) s. 191-214; tenże Początki Misji Dyplomatycznej Giovanniego Battisty Lancellottiego, 31-szego nuncjusza apostolskiego w Polsce (1622-1627), „Roczniki Teologiczne”, 46 (1999) z. 4, s. 79-118; tenże, Pierwsze wizytacje kolegiów papieskich w Polsce (Z działalności G. B. Lancellottiego nuncjusza apostolskiego w Polsce (1622-1627), w: W kręgu chrześcijańskiego orędzia moralnego. Księga Jubileuszowa poświęcona czci Księdza Profesora Antoniego Młotka, red. M. Biskup, T. Reroń, Wrocław 2000, s. 723-756; tenże, Obecność nuncjusza Giovanniego Battisty Lancellottiego na sejmach, „Saeculum Christianum”, 5 (1998) nr 2, s. 145-194. 


\section{STAN DIECEZJI NA POCZĄTKU XVII WIEKU}

\section{Dzieje regionu i położenie diecezji}

Przechodząc do scharakteryzowania diecezji Nola na początku 17 stulecia, ale istniejącej już od II w. ${ }^{10}$, wypada odnotować fakt, że chociaż pierwsze bazyliki S. Felice in Pincis i siedziba biskupa, aż do początków XV w. znajdowała się w pobliskim słynnym Cimitile ${ }^{11}$, to jej stolicą zawsze było miasto Nola (Mapa 1). Miasto położone jest na wysokości $34 \mathrm{~m}$ nad poziomem morza, na skrzyżowaniu szlaków komunikacyjnych przebiegających w malowniczej dolinie oddzielającej Wezuwiusz od Apeninu neapolitańskiego, oddalone $26 \mathrm{~km}$ na wschód od Neapolu oraz $22 \mathrm{~km}$ od Caserty ${ }^{12}$.

Nola jako miasto powstało o 48 lat wcześniej niż Rzym ${ }^{13}$. Po ekspansji kolonizacyjnej Greków od 8/7 w. p. Chr. stanowiło ono najpierw antyczne centrum Ausonówi Osków. W okresie umacniania sięna półwyspie wpływów greckich ietruskich w VI w. przed Chrystusem Nola wraz z Kapuą stała się jednym ze znaczących centrów Etrusków ${ }^{14}$, a wiek poźniej miasto to przeszło już w posiadanie Samnitów, pod nazwą Novle (nowe miasto) ${ }^{15}$.

${ }^{10}$ Zob. Nola, w: G. Moroni, Dizionario di erudizione storico-ecclesiastica, t. 48, Venezia 1848 , s. 70-73; Annuario Pontificio, Cittá del Vaticano1993, s. 474; Enciclopedia Cattolica, t. 8, k. 19121916; Enciclopedia Italiana di scienze, lelere ed arti, t. 25, Roma 1950, 887-888; Grande Dizionario Enciclopedico, t. 14, [Torino 19894'], s. 601; LfThK, t. 7, Friburg 1962, k. 1019.

${ }^{11}$ Zob. L. D'Avanzo, Cimitile celebre dopo Roma, Nola 1931.

${ }^{12}$ Zob. R. Amagiá, Studi storici di cartografia napoletana, „Archivio storico per le province napoletane", 37 (1913) s. 318-319; G. Moroni, Nola, w: Dzionario di erudizione, t. 48, s. 70-73.

${ }^{13}$ Najnowsze opracowania dziejów miasta i regionu przynoszą m.in. prace: R. Ciro, Storia di Nola, 1991; AA.VV., Storia della Campagna, red. F. Barbagallo, Napoli 1978 oraz AA. VV., Nola cittá millenaria, red. G. Minieri, Nola 1981; A. Minieri, Storia di Nola dalle origini ai nostri giorni, Nola 1983; P. Moschiano, La terra di Lauro nei secoli. Sintesi storica, w: Didattica e Teritorio (Corso di formazione per docenti in servizio, 30 marzo - 8 giugno 1988), XXX Distretto Scolastico - Nola, [Nola 1990], s. 107-124; Nola e il suo teritorio dalla fine del medio evo al XVII secolo momenti di storia culturale e artistica (Atti del II corso di Formazione per docenti in servizio "Diattica e Teritorio" 10 febbraio - 28 maggio 1994), red. T. R. Toscano, Colanna di testi e studi di storia nolana - Ager Nolanus 5, Distretto Scolastico Nola [Castellammare di Sabia, Somma] 1996; Nola e il suo teritorio dalla fine del medio evo al XVII secolo momenti di storia culturale e artistica (Atti del III corso di Formazione per docenti in servizio "Diattica e Teritorio"), red. T. R. Toscano, Colanna di testi e studi di storia nolana - Ager Nolanus 5, Distretto Scolastico Nola [Castellammare di Sabia, Somma] 1998.

${ }^{14} \mathrm{~W}$ opinii naukowców brak jednomyślności. Twierdzą oni, że Etruskowie to lud, który ok. IX w. p. Chr. przybył do Italii z zachodniej lub północnej Anatolii, jak też że jest to autochtoniczny lud Etruii. Niemniej w efekcie przymierza dwunastu miast-państw z północnej Italii rozwijali oni handel z koloniami greckimi i już w VI w. p. Chr. stali się najpotężniejszym ludem w tej części półwyspu, który coraz bardziej wypierał rodzime ludy Ligurów, Latynów i Sabinów.

${ }^{15}$ Zob. V. Sampaolo, Nola preromana. Dalle necropoli di Piazza d'Armi, Ronga, S. Massimo, Nola, Catalogo della mostra Nola 1985; M. Bonhi Jovino i R. Doncell, La necropoli di Nola preromana, Napoli 1969; R. Bianchi Bandinelli, Etruschi e Italici prima del dominio di Roma, Milano 1973; B. D'Agostino, Popoli e civiltá dell'Italia antica, Roma 1976. 
W 311 roku zajęli Rzymianie z Fabio Quinto na czele, którzy po opanowaniu w roku 275 Benewentu, zaprowadzili już swą władzę na znacznym obszarze Włoch południowych oraz uczynili z Nola bazę wypadową dla najazdów przeciwko Kartagińczykom ${ }^{16}$. Wespazjan nadał miastu nzawę Colonia Augusta. W epoce cesarstwa osiedlały się tu na stałe rodziny procesarskie. To m.in. właśnie tu, w Nola w 14 roku zmarł cesarz Oktawian August, a przed nim w 12 roku Marek Agrypa $^{17}$.

Do kolejnego rozkwitu Nola doszło za panowania Wespazjana i w czasach pierwszych chrześcijan, dla których miasto było jednym z głównych centrów, a na przełomie II i III w. siedzibą biskupa ${ }^{18}$. Po upadku cesarstwa rzymskiego region Neapolu (gr. Neá Polis, łac. Neapolis) stał się terenem rywalizacji królestwa Ostrogotów i Bizancjum. W konsekwencji w roku 410 Nola została spustoszona przez Gotów. Natomiast w 455 roku po kolejnym jego zniszczeniu przez króla Wandalów, następuje panowanie Bizancjum (455-570). Wreszcie po okresie najazdów barbarzyńców i rosnących wpływów bizantyjskich nastapiła w tej części Półwyspu Apenińskiego epoka dominacji germańskiego plemienia Longobardów, a od VIII w. także Franków - ortodoksyjnych chrześcijan wywodzących się z Galii.

Po inwazji dokonanej w 568 roku przez króla Longobardów, który utworzył księstwo ze stolicą w Benewencie (570) ${ }^{19}$, Nola stała się jego częścią, a biskup Bazyli na skutek zniszczeń, już w 571 roku musiał przenieść się z Noli do pobliskiego Neapolu. Cenne relikwie San Massimo i San Paolino zabezpieczono w Benewencie, szczątki San Paolino zaś za czasów Ottona III przeniesiono po raz kolejny, tym razem do Bazyliki św. Bartłomieja w Rzymie. Samo miasto Nola zostało co prawda niebawem w pełni odbudowane, ale nie odzyskało już swego antycznego prestiżu i bizantyjskiego charakteru. Średniowiecze zaznaczyło się dla Noli kolejnym długim okresem dekadencji, spowodowanym najpierw najazdami Saracenów (798 i 860); przy czym już w 849 roku Nola przeszła pod patronat księstwa Salerno). Po zniszczeniu miasta w roku 939 Nola ponownie dzieli losy Neapolu, tzn. doświadcza najazdy Arabów i uznaje panowanie Normanów, którzy podbili Sycylię, Kalabrię i Apulię (w 1130 roku Roger II koronowany na króla). W roku 1139 za Anakleta II Nola przeszła jednak pod władzę Królestwa Sycylii.

W sytuacji, kiedy kwestia supremacji aż na okres dwóch wieków podzieliła całą średniowieczną Italię, bowiem w każdym regionie byli propapiescy gwelfowie, jak też opowiadający się po stronie cesarza gibelinowie, diecezja Nola znalazła się w roku 1194 pod panowaniem rodziny Hohenstaufów, z którymi poprzez

${ }^{16}$ V. Quindici, Nola Romana, w: Didattica e Teritorio (Corso di formazione per docenti in servizio, 30marzo - 8 giugno 1988), XXX Distretto Scolastico - Nola, [Nola 1990], s. 73-86.

${ }^{17}$ Zob. także F. D'Ascoli, Ottaviano: terra di Augusto, Napoli 1985.

${ }^{18}$ Zob. H. Leclerq, Nole, w: Dictionaire d'archéologie chrétienne et de liturgie, publié par F. Garol e H. Leclerq, t. 12, Paris. 1936, k. 1422-1465.

${ }^{19}$ W okresie od 1077-1798 Księstwo Benewentu należało do Państwa Kościelnego, pozostając otoczone prze Królestwo Neapolu. 
małżeństwo połączyłsięsyn cesarza HenrykaFryderyk II $(† 1250)^{20}$, któryjużw 1224 roku założył w Neapolu uniwersytet, pierwszy w tej części Włoch.

Z kolei w okresie powstawania w Italii miast-państw Karol Andegaweński, brat króla Francji Ludwika IX, pokonał spadkobierców Fryderyka II w południowych Włoszech i jako nagrodę otrzymał od papieża Neapol i Sycylię. W takiej sytuacji politycznej również feudum kościelne Nola, zostało w roku 1266 przekazane pod jego władzę w ramach rocznych kontrybucji. W dalszej konsekwencji Nola wchodziła najpierw w skład feudum, na czele którego stał m.in. książę Guido di Monfort (od 1269 roku, nagrodzony w ten sposób przez króla Neapolu Karola Andegaweńskiego ${ }^{21}$, za pomoc w wojnie przeciwko królowi Sycylii Manfredo $1232-1266^{22}$ ).

Z chwilą rozpadu Królestwa Sycylii (w 1282 roku - nieszpory sycylijskie) i powstania Królestwa Neapolu (które z końcem XIV w. wzbogaciło się jeszcze o płd. krańce Państwa Kościelnego, a nawet i Toskanii) niebawem rozpoczęła się epoka dominacji aragońskiej (po 1435) ${ }^{23}$. W XV w. pięć najpotężniejszych państw Italii: Neapol, Państwo Kościelne, Mediolan oraz republiki Wenecji i Florencji zawarło niepisaną umowę o podtrzymaniu ówczesnej równowagi sił. Wówczas to feudo Nola stawało się własnością kolejno aż dziesięciu książąt z rodziny

${ }^{20}$ Fryderyk II, w wieku zaledwie trzech i pół lat zasiadł na tronie cesarskim i odziedziczył normańskie Królestwo Sycylii. W sprawowaniu nieustabilizowanej władzy napotkał opór ze strony miast włoskich i papiestwa i w efekcie wybuchła wojna domowa. Sprawę rozwiązała nagła śmierć Fryderyka II w roku 1250.

${ }^{21}$ Po wyeliminowaniu Manfreda i Konrada IV (†1254) syna króla Fryderyka II von Hohenstauff, papież Klemens IV z obawy przed odrodzeniem się Gibelinów, koronę królestwa Sycylii powierzył Karolowi Andegaweńskiemu, bratu Ludwika IX, świętego króla Francji. Niestety okrutne akty wszechmocnego panowania Francuzów w roku 1282, spowodowały, iż doszło na Sycylii do powstania zwanego nieszporami sycylijskimi. Na głos dzwonów wzywających na nieszpory w Palermo zostało zamordowanych 2000 żołnierzy wojsk okupacyjnych. Sycylijczycy znaleźli jednak pomoc u króla Piotra II Aragońskiego (Francuzi przez 20 lat byli z nim w stanie wojny), a któremu przekazali koronę Sycylii. Ten poślubił Costanzę, córkę Manfreda. Wojna zakończyła się pokojem w Caltabellotta w 1302 r. na mocy którego dom d'Angio (prezentowany w płd. Italii w r. 1246 przez Karola Andegaweńskiego przetrwał tam do roku 1480) zachował terytorium Neapolu, a Fryderyk syn Pietra Aragońskiego zatrzymał Sycylię i nosił tytuł „Re di Trinacria”.

${ }^{22}$ Był on królem Sycylii, a synem Fryderyka II i Lancii Bianca wywodzącej się z rodziny należącej do stronnictwa gibelinów.

${ }^{23}$ Malejącej władzy wielkich potęg (cesarstwo było w defensywie, a Klemens V w roku 1309 przeniósł siedzibę papiestwa do Awinionu) towarzyszyła rosnąca autonomia wielkich miast. $\mathrm{Na}$ początku XIV w. środkowa i północna cześć Włoch stanowiła szeroki pas ok. 300 niezależnych miast-państw. Pod koniec tego wieku najbardziej bogate i wpływowe z nich tzn.: Genua, Florencja, Mediolan i Wenecja, wchłonęły mniejsze ośrodki. W wieku XV jeśli na północy i w centrum Włoch większość państw-miast była już pod zwierzchnością książęcą, a nie republikańską, to Państwo Kościelne rozciagało się (z wyjątkiem wyspowej części Benewentu) od Rzymu do dzisiejszej Marchii, Umbrii i Romanii. Samodzielnymi i niepodległymi państwami obok Księstwa Mediolanu i dwu morskich republik Wenecji i Genui były Siena, Florencja, Modena, Mantua i Ferrara. Natomiast na południu tak bardzo podzielonego półwyspu znajdowało się Królestwo Neapolu. 
Orsinich, którzy którzy byli wielkimi mecenasami życia religijnego ${ }^{24}$. Po udowodnieniu współpracy ostatniego z Orsinich z Francuzami i Wenecjanami w roku $1528^{25}$ feudo zostało mu odebrane i powróciło pod władzę króla Neapolu dzieląc odtąd dalszy bieg jego historii (Mapy 2 i 4a) ${ }^{26}$. Pomimo iż w latach 1495-1503 w Królestwie Neapolu, ponownie wybuchły walki pomiędzy Francją i Hiszpanią o prawo do tronu, to ostatecznie aż do roku 1715 Habsburgowie hiszpańscy utrzymali tu swe panowanie ${ }^{27}$. Po nich, do roku 1738, władzę przejęli Habsburgowie austriaccy, aż wreszcie Królestwo Neapolu zyskali hiszpańscy Burboni, zachowując tu swe wpływy do roku 1799.

W połowie XVI w. recesja gospodarcza panująca w Italii skłoniła nawet bogatych kupców weneckich i florenckich do inwestowania w ziemię, a nie w przedsiebiorstwa, a na południu wysokie podatki i represyjne reżimy feudalne stały się przyczyną rosnącego oporu ze strony chłopów. Z kolei w wieku XVII miała tam miejsce m.in. krwawa rewolta Masanielliego (1647), a także bolesna w skutkach zaraza (1656-1657), która zredukowała liczbę mieszkańców aż do 200.000. W Italii najdotkliwiej dała się ona odczuć w Ligurii i Królestwie Neapolu gdzie zmarło wówczas $50 \%$ mieszkańców ${ }^{28}$.

Należy jednak mieć tu na uwadze fakt, że miasto Neapol już od czasów panowania rodziny Angio (1268), a następnie Aragona (1442-1501) doznawało wielkiego rozkwitu i aż do chwili zjednoczenia Włoch było ono stolicą największego państwa skupiającego nie mniejszą uwage jak Paryż czy Madryt. I tak jeśli jeszcze za panowania Andegawenów tamtejsza ludność stanowiła zaledwie 60.000, to już

${ }^{24}$ Byli to: Romano, Roberto (†1344), Niccolň (†1399), Pirro (†1420), Raimondo $(\dagger 1459)$, Felice $(\dagger 1460)$, Orso (†1479), Raimondo, Nicola ( $† 1509)$ i Enrico $(\dagger 1533)$. Zob. V. Quindici, La Signoria degli Orsini a Nola (1290-1533), w: Nola e il suo teritorio dalla fine del medio evo al XVII secolo momenti di storia culturale e artistica (Atti del II corso di Formazione per docenti in servizio "Diattica e Teritorio" 10 febbraio - 28 maggio 1994), red. T. R. Toscano, Colanna di testi e studi di storia nolana - Ager Nolanus 5, Distretto Scolastico Nola [Castellammare di Sabia, Somma] 1996, s. 9-18.

${ }^{25}$ Karol V $(500 \nmid 1558)$ odziedziczył tron austriacki i hiszpański oraz zapewnił sobie koronę Świętego Cesarstwa Rzymskiego, a w roku 1527 jego wojska zajęły Rzym. Wysuwający roszczenia Andegawenów Francuzi zostali pobici w 1525r. pod Pawią, a w 1529 r. pod Neapolem. W ramach zawartego w 1559 r. traktatu w Chateu-Cambresis - Hiszpania otrzymała Sycylię, Neapol, Sardynię, księstwo Mediolanu i kilka twierdz toskańskich, aby silną ręką przez następne 150 lat kierować włoską sceną polityczną. Pozostałe mniejsze włoskie miasta-państwa stały się satelitami zwierzchności hiszpańskiej lub francuskiej. Jedynie papiestwo i Wenecja zachowały niepodległość.

${ }^{26}$ Zob. Giovanni Battista Pacichelli, Il Regno di Napoli In Prospettiva - diviso in dodeci provincie, cz. 1, Napoli 1703, s. 114; N. Cortese, Feudi e feudatari napoletani nella prima metá del cinquecento, „Archivio Storico per le provinze napoletane”, seria 2, t. 54 (1929); P. Colletta, Storia del Reame di Napoli, a cura di N. Cortese, Napoli 1957³; G. Vincenti, La Contea di Nola dal secolo XIII al XVI, Napoli 1987.

${ }^{27}$ W życiu politycznym Włoch XVII w. narastał kryzys.. Natomiast Hiszpanie ostatecznie utracili kontrolę nad Italią z początkiem XVII w., kiedy to (na skutek wojny sukcesyjnej w Hiszpaniii) Lombardia, Mantua, Neapol, i Sardynia przeszły we władanie Austrii. W roku 1734 Neapol i Sycylia przeszły w ręce hiszpańskich Burbonów.

${ }^{28}$ Zob. A. Kersten, Historia Powszechna - wiek XVII, Warszawa 1987, s. 8. 
z końcem XV w. spotykamy w Neapolu 100.000 mieszkańców, a z końcem XVII wzrosła ona kilkakrotnie osiągając wielkość aż 360.000 ludności $^{29}$.

Usiłując chociażby częściowo przybliżyć wielkość populacji tego miasta musimy stwierdzić, iż z końcem XV w. wśród 4000 mieszkańców Nola było już 600 rodzin, a w tym już 115 rodzin nobilitowanych. Natomiast w całym feudo żyło dalszych 6.000 osób. A przy tym dodajmy, że w roku 1528 Neapol, stolicę królestwa zamieszkiwało 155 tys. ludzi a w roku 1614 liczba mieszkańców się już podwoiła i wynosiła 327 tys. osób ${ }^{30}$. Nie możemy też tu pominąc istotnego faktu, iż w wieku XVI stolica Królestwa Neapol, dzięki grupie humanistów z kręgu Waldensów (założonych ok. 1170 w Lyonie przez P. Valdčsa, a ekskomunikowanych już w 1184 roku) stał się centrum myśli reformacyjnej dla całych Włoch ${ }^{31}$.

Jeśli natomiast idzie o organizację kościelną to pierwszym biskupem diecezji Nola był San Felice - męczennik (85-95), a jego następcą San Massimo (95$120)^{32}$. Na początku $X$ wieku przez krótki czas Nola stanowiła nawet metropolię, której sufraganią była diecezja Salerno ${ }^{33}$. Natomiast od drugiej połowy wieku XII obszar diecezji Nola nie przekroczył nigdy powierzchni $200 \mathrm{~km}^{2}$ i od tej doby była już ona sufraganią Neapolu ${ }^{34}$. Z kolei w roku 1529 w Królestwie Neapolu

${ }^{29} \mathrm{Z}$ tym wiązała się $\mathrm{m}$. in. konieczność szybkiego rozwiązania problemu zabezpieczenia dostaw wody i higieny, co dokumentują kompleksowe rozwiązania budowy kilkunastu kilometrów nowych akweduktów i kanałów m.in. autorstwa Pietro di Toledo (1532-1553), przemierzających z jednej strony przez Nocerra a z drugiej także przez Nolę, przy czym ostatnie z nich ukończono dopiero w roku 1629. Zob. G. Fiengo, I Regi Lagni e la bonifica della Campania Felix durante il Viceregno spagnolo, Firenze 1988.

${ }^{30}$ Zob. G. Fiengo, Progetti e realizzazioni per il risanamento e lo sviluppo di Napoli e la bonifica di Terra di Lavoro 1592-1631, w: Nola e il suo teritorio dalla fine del medio evo al XVII secolo momenti di storia culturale e artistica (Atti del III corso di Formazione per docenti in servizio „Diattica e Teritorio”), red. T. R. Toscano, Colanna di testi e studi di storia nolana - Ager Nolanus 5, Distretto Scolastico Nola [Castellammare di Sabia, Somma] 1998, s. 15.

${ }^{31}$ Zob. R. Pane, Il Rinascimento nell ,Italia meridionale”, t. 1, Milano 1975; J. Martin, Venice's Hidden Enemies. Italian Heretics in A Renaissance City, Berkeley-Los Angeles - London [1993]; R. E. Hedlund, Movement in Italy. Its Progress, Problems and Prospects, South Pasadena, California [1970]; L. Ammirati, Nola nella luce della Rinascenza, Nola 1980; tenże, Il collegio nolano delle monache rocchettine tra riforma e controriforma, Nola 1988.

${ }^{32}$ Zob. L. Angelillo, La chiesa cattedrale e i vescovi di Nola attraverso la storia, [Nola 1979], s. 12.

${ }^{33}$ Zob. L. Avella, Presentazione di una copia manoscritta inedita relativa ai confini territoriali della cittá di Nola nel 1639 con i suoi casali (...), Napoli 1977; tenże, Le tavole di bronzo della cittá di Nola, Nola 1970.

${ }^{34}$ Zob. m.in. G. Galasso, Alla periferia dell'impero. Il Regno di Napoli nel periodo spagnolo (secoli XVI-XVII), Torino 1994. Natomiast aktualne problemy Kościoła katolickiego w Królestwie Neapolu na początku XVII w. ze szczególną wyrazistością przybliżają zwłaszcza instrukcje ogólne jakie otrzymali dwaj nuncjusze - Valeriano Muti (15 I 1609) i Paolo Emilio Filonardi (22 IV 1616). Zob. S. Giordano, Le istruzioni generali di Paolo V ai diplomatici pontifici 1605-1621, t. 2 , Tübingen 2003, nr 39 i 80, s. 605-611, 1006-1013. 
było aż 20 siedzib arcybiskupich i 127 biskupich, przy czym król mial prawo nominacji odnośnie 8 stolic arcybiskupich i 16 biskupich $^{35}$.

Lokalizując diecezję Nola na mapie dokumentującej organizację metropolii i diecezji ówczesnego Kościoła Katolickiego w południowej Italii (Mapa 2). Podążając z Nola zgodnie z ruchem wskazówek zegara najpierw na północny zachód $^{36}$, znajdujemy najbliższe stolice metropolitalne z siedzibami w Kapui, Benewencie, Conza, Salerno, Amalfi i wreszcie Neapolu ${ }^{37}$. Z kolei w XVII-wiecznej sieci diecezjalnej najbliższe w stosunku do Noli stolice biskupie znajdujemy między innymi w Acerra, Aversa (była ona zależna bezpośrednio od Rzymu), Caserta, S. Agata dei Goti, Montemarano, Avellino, Sarno i Nocera ${ }^{38}$.

\section{Wybitni hierarchowie}

Pierwszym biskupem Noli, jednego z najstarszych i najbogatszych miast Kampanii, był św. Feliks, a czternastym z kolei i najbardziej znanym jego następcą - św. Paulin z Noli (409-431), rodem z Bordeaux w Akwitanii. Ponzio Meropio Anicio Paolino (ur. 353) wywodzący się z bogatej, nobilitowanej rodziny rzymskiej (jego ojciec był wysokim urzędnikiem rzymskim), który po zdobyciu w szkole Ausoniusza sławy genialnego oratora i poety (jest uważany za jednego z największych chrześcijańskich wieszczów swojej doby), we Włoszech realizował karierę senatora i konsula, dzięki czemu poznał wielu wybitnych biskupów (św. Marcina z Tours, Witryka z Rouen, św. Ambrożego z Mediolanu), którą najpierw naznaczył chrzest przyjęty ok. 389 roku, a następnie wybór na biskupa Noli ${ }^{39}$.

${ }^{35}$ Zob. - Ch. Weber, Familien Kanonikate und Patronatsbistümer. Ein Beitrag zur Geschichte von Adel und Klerus im neuzeitlichen Italien, Berlin 1988, s. 46-47.

${ }^{36}$ Zob. G. B. Pacichelli, Il Regno i Napoli in prospettiva, t. 3, Napoli 1702-1703; D. Romanelli, Antica topografia istorica del Regno di Napoli, Napoli 1815-181933; A. Romano, Il Teritorio nolano nella storia, 1988; F. Sacco, Dizionario geografico-istorico-fisico del Regno di Napoli, Napoli 1796; G. Strafforello, La Patria. Geografia dell'Italia. Provincia di Avvelino, Benevento, Caserta, Salerno, Torino 1898.

${ }^{37}$ Zob. m.in. L. Giustiniani, Dizionario geografico-ragionato del Regno di Napoli, Napoli $1804-1805^{10}$.

${ }^{38}$ Zob. M. Miele, Die Provinzialkonzilien Süditaliens in der Neuzeit, Konziliengeschichte, wyd. W. Brandmüller, Reihe A : Darstellungen, Padeborn 1996; O. Beltrano, Breve descrizione del Regno di Napoli diviso in dodeci provincie, Napoli 1644, 1671 (reprint - Forni 1983); S. Carillo, Alcune osservazioni sulla pianta della cittŕ allegata al De Nola di Ambrogio Leone, w: Nola e il suo teritorio dalla fine del medio evo al XVII secolo momenti di storia culturale e artistica (Atti del II corso di Formazione per docenti in servizio "Diattica e Teritorio" 10 febbraio - 28 maggio 1994), red. T. R. Toscano, Colanna di testi e studi di storia nolana - Ager Nolanus 5, Distretto Scolastico Nola [Castellammare di Sabia, Somma] 1996, s. 25-43.

${ }^{39}$ Ten pierwszy biskup Noli, urodzony w 353 r. w Bordeaux, był przedstawicielem patrycjatu rzymskiego spokrewnionego z rodziną licznych konsulów Anicci. Ponzio Meropio Anicio Paulino był kolejno senatorem, konsulem i gubernatorem Kampanii, a po nawróceniu na chrześcijaństwo zakonnikiem i wreszcie biskupem Noli. Zob. 22 czerwca, w: Martyrologium Rzymskie, Kraków [1968], s. 180; M. Cipriano - Paulino di Nola - Uranio, red. M. Ruggiero, w: Collana di testi patris- 
Rezydował on w pobliskim Cimitile, w pobliżu grobu św. Feliksa gdzie założył swego rodzaju klasztor ${ }^{40}$.

Z końcem XV w. diecezja przez pewien czas miała nawet wikariusza generalnego w osobie św. Kamila de Lellis. Również i w wiekach poźniejszych nie brakowało tu hierarchów wybitnych i zasłużonych dla Kościoła. Spoglądając na cały szereg ordynariuszów tej diecezji aż do końca XVII w. stwierdzamy, że wywodzili się oni głównie z Neapolu ${ }^{41}$ i z samego miasta Nola ${ }^{42}$. Co więcej, jeśli do roku 1615 na tej stolicy nie zasiadał żaden przedstawiciel Rzymu, to także w znacznie mniejszym stopniu nominacją tą byli obdarzani przedstawiciele Włoch Północnych i Środkowych. Nie mniej, wielu z nich pochodziło z dobrze znanych nobilitowanych rodzin włoskich jak Caraffa, Orsini ${ }^{43}$, czy też w XVII w. z rodu Canalla ${ }^{44}$. Nie bez znaczenie jest też fakt, iż czterech $\mathrm{z}$ nich zostało promowanych godnością kardynalską ${ }^{45}$. W dziewiątym stuleciu po raz pierwszy godność tę otrzymał Giovanni II 36. biskup Noli, a w wieku XII Bartolomeo i Ruffino (przeniesiony najpierw do Rimini). Z kolei po kilkuwiekowej przerwie, bowiem dopiero 13 grudnia roku 1580, godność kardynalską otrzymał 72. biskup tejże diecezji Filippo Spinola (rodem z Genui), przybyły z diecezji Bisignano.

Ponadto należy tu zauważyć, że tutejsi ordynariusze często pełnili misje legatów papieskich, jak też z pełnym zaangażowaniem uczestniczyli w pracach soborów. Przykładowo Leone I $(† 560)-24$. biskup Noli już w roku 535 był legatem papieskim na dworze w Konstantynopolu. Z kolei biskup Bartłomiej w roku 1179 wystapił na soborze Lateraneńskim III i wkrótce został kardynałem. Wybitną osobistością był też kanonik katedralny z Noli Francesco III Scaccano, 63. biskup Noli (1370-1400), którego Bonifacy IX wysłał w legacji na Sycylię a później za-

tici, red. A. Quaguarelli, t. 42, Roma 1984, s. 45-47; F. Renato de Luca, Vescovi di Nola appartenenti alla nobiltŕ, "Rivista Araldica" 77(1979), n. 7, s. 144.

${ }^{40}$ Zob. Paolino di Nola. I carmi (trad. e comm.), red. A. Ruggiero, t. 1-2, Nola 1996; Anchora vitae. Atti del II Convegno Paoliniano nel XVI Centenario del Ritiro di Paolino a Nola (Nola Cimitile 18-20 maggio 1995), red. G. Luongo, Nola 1998; jedną z najbardzie aktualnych bibliografii na temat św. Paolina z Noli opublikował C. Iannicelli - zob. Rassegna di Studi Paoliniani (19801997), w: „Impegno e Diaologo”, 11 (1994-1996) s. 279-321.

${ }^{41}$ Byli to kolejno 54. biskup Noli - Antonio Caraffa, 60. - Nicedo II, następnie w wieku XV 65. biskup i zarazem doradca królowej Izabeli, a wieku XVII 72. - Fabrizo Gallo (†1614) oraz 76. - Francesco Maria Moles (†1695).

${ }^{42}$ Spośród pięciu biskupów, z rodziny książęcej wywodził się tylko Orlando Orsini (1475-1504), natomiast jego trzej porzedni krajanie na tym uzrędzie reprezentowali tutejszy patrycjat i często byli członkami kapituły. Wśród nich znajdujemy: Adeodata (†473), Francesco III (1370-1400), Flaminio Mantuolo (1402-1442) i Filippo Cesariniego (1674-1683).

${ }^{43}$ Do takich należy zaliczyć w roku 1475 Orlando Orsiniego, rzymianina cenionego humanistę i słynnego rektora rzmskiego uniwersytetu. Zob. G. Moroni, Nola, w: Dizionario di erudizione, t. 48 , Venezia 1848 , s. 72 .

${ }^{44}$ Zob. R. F. de Luca, Vescovi di Nola appartenenti alla nobiltá, „Rivista Araldica”, 77 (1979) nr 7, s. 144-147.

45 35. biskupem Noli był Giovanni (XI w.), 43. Bartolomeo (od 1179), a 71. Filippo Spinola (w roku 1580). W lakoniczny sposób wspomina o tych faktach G. Moroni - zob. Nola w: Dizionario di erudizione storico-ecclesiastica. t. 48, s. 71-72. 
mianował wikariuszem na Rzym. Ponadto na soborze Lateraneńskim V aktywnie uczestniczył protonotariusz apostolski Giovanfrancesco Bruno (ur. 1485; papież Juliusz II pomimo jego młodego wieku 20 lat zamianował go 70. administratorem diecezji Nola, a jego posługiwanie przypadające na okres 1505-1549, należy zaliczyć do jednego z najdłuższych ${ }^{46}$. Natomiast w roku 1549 jego następcą został przedstawiciel książęcej rodziny z Piemontu Antonio II Scarampo (1549-1568), który z kolei uczestniczył w obradach Soboru Trydenckiego ${ }^{47}$, a następnie erygował w Nola seminarium duchowne (jedno z pierwszych w całych Włoszech) ${ }^{48}$, położył kamień węgielny pod klasztor jezuitów (którzy w Reggia - rezydencji Orsinich otworzyli kolegium na rzecz formacji młodzieży), a w roku 1551 przeprowadził on jedną z pierwszych wizytacji pastoralnych opisując stan religijny diecezji ${ }^{49}$, a na koniec został przeniesiony na stolicę biskupią w Lodi.

Na przełomie XVI i XVII wieku, 72. z kolei biskupem diecezji Nola, był Fabrizio Gallo (1585-1614), rodem z Neapolu. Człowiek znany z głębokiej pobożności, ascetycznego sposobu życia, a zarazem wielkiej otwartości i miłości pasterskiej wobec ludzi. W dniu 1 lipca 1585 roku został on zamianowany na tutejszego ordynariusza, a już od 1586 roku odważył się na ogromne przedsięwzięcie i przez całe 8 lat wznosił katedrę pod wezwaniem Wniebowzięcia Najświętszej Maryi Panny i Świętych Męczenników Feliksa i Paulina ${ }^{50}$. Potrzeba taka zaistniała po zawaleniu się w roku 1583 trzynawowej gotyckiej katedry (wzniesionej zaledwie przed 194 laty) ${ }^{51}$. Była ona czwartą z kolei budowlą kościelną tego typu, a zarazem pierwszą katedrą wzniesioną w mieście Nola ${ }^{52}$ (Mapa 4). W trakcie odbudowy tzn. w latach 1586-1594, funkcję katedry czasowo przeniesiono na

${ }^{46}$ Została po nim dobrze zachowana, kompletna seria dokumentów w formie bulli biskupich. Zob. R. F. de Luca, L'Archivio Storico Diocesano di Nola, w: Nola e il suo teritorio dalla fine del medio evo al XVII secolo momenti di storia culturale e artistica (Atti del III corso di Formazione per docenti in servizio „Diattica e Teritorio”), red. T. R. Toscano, Colanna di testi e studi di storia nolana-Ager Nolanus 5, Distretto Scolastico Nola [Castellammare di Sabia, Somma] 1998, s. 249.

${ }^{47}$ Zob. G. Alberigo, I vescovi italiania al concilio di Trento, Firenze 1959.

${ }^{48}$ W latach 1564-1584 powstało ok. 20 seminariów duchownych. Dodajmy jednak że w Hiszpanii w całym półwieczu 1565-1615 erygowano ich tylko 26, a we Francji zaledwie ok. 10. Zob. G. Zagheni, L'etá moderna. Corso di storia della Chiesa - III, [Milano 1995], s. 195.

${ }^{49}$ Zob. m.in. S. Giuliano, La Chiesa cattedrale e $i$ Vescovi di Nola attraverso la Storia (Brevi notizie desunte dall'opere di Mons. Angelillo), Nola [1979], s. 6-16; F. Ughelli, Italia sacra sive de episcopis Italiae et insularum adiacenttium, Roma $1662^{2}$, Venezia 1717-1722².

${ }^{50}$ Nic dziwnego, że na fasadzie tejże katedry umieszczono epigram: „Fabrbricius - Gallus Neapo / Nolan - Pont / Collapsum - acceperat - aere / suo - et - publico / magnificentius - Restituit / An - D. M.D.XCIV".

Zob. L. Angelillo, La chiesa cattedrale e i vescovi di Nola attraverso la storia, [Nola 1979], s. 17 i 25.

${ }^{51}$ Budowana od 1395 r. katedra gotycka miała wraz z absydą 42,5 m długości, 43,5m wysokości a jej 2 nawy boczne miały szerokość 10,4 m. Biskup Gian Antonio Tarentino wyposażył ją w stalle chórowe dla tamtejszych kanoników.

${ }^{52}$ Zob. L. Angelillo, La catedrale di Nola nella sua storia, Napoli 1909, tenże, La chiesa cattedrale e i vescovi di Nola attraverso la storia, [Nola 1979]; S. Carillo, La Cittá attorno alla cattedrale (Il restauro del Duomo di Nola e la sua influenza sull'assetto urbano, a cura dei Maestri di Festa della 
pobliski kościół SS. Apostoli (który od 1642 roku służył jedynie kultowi zmarłych). W następnych latach nie tylko rozbudował i upiększył kurię biskupią, ale zainicjował także budowę kościoła pielgrzymkowego Santa Maria dell'Arco ${ }^{53}$, powiększył liczbę kościołów kolegiackich i sprowadził do diecezji kamedułów eremitów ${ }^{54}$. Ponadto w latach 1588, 1590, 1592, 1594 i 1602 zdołał on także przeprowadzić synody biskupie ${ }^{55}$. Natomiast $\mathrm{w}$ czterech ostatnich latach życia nie cieszył się już najlepszym zdrowiem i dlatego do przeprowadzenia wizytacji diecezji oddelegował w roku 1610 kanonika gremialnego Antonio Cuboni i jednego przedstawiciela kapituły katedralnej ${ }^{56}$, a w roku 1613 kanonika Giovanniego Battistę Vincenta upoważnił do złożenia wizyty ad limina ${ }^{57}$. Pomimo tego nawet na tym etapie życia tzn. jeszcze w roku 1610, kontynuwał on wykańczanie i upiększanie katedry ${ }^{58}$, a w roku 1612 przeprowadził wizytację, która poświadcza istnienie w diecezji ponad 40 kościołów $^{59}$, a wreszcie w 1613 roku zdołał nawet zaadaptować część katedralnej budowli na zakrystię oraz zbudować kaplicę, umieścić tam relikwie św. Feliksa, współpatrona kościoła biskupiego. Biskup Fabrizio Gallo zmarł 5 listopada 1614 roku i został pochowany, w zbudowanej przez siebie samego, drugiej z kolei katedrze miasta Nola, w kaplicy św Stefana.

\section{Katedra i sieć kościołów}

Siedziba pierwszych biskupów Noli aż do XIV w. znajdowała się w słynnym kompleksie bazylik paleochrześcijańskich. Pierwsza bazylika tego typu została wzniesiona z końcem I w. w Cimitile. W pobliżu drogi wiodącej z Pulii do Neapolu, znajował się słynny cmentarz (katakumby) miasta Nola. To właśnie tutaj na polu o nazwie Pincio, na dawnych ruinach pogańskiej świątyni Apolla zbudowano kościół należący do pierwszego biskupa. W IV w. bazylika ta była dedykowana San Felice'mu ${ }^{60}$. W IV w. pielgrzymowano doń z całych Południowych Włoch. W ro-

Corporazione dei Panettieri - Nola, Nola] Festa dei Gigli 1989; C. Guadagni, Nola Sagra (1688), red. T. R. Toscano, Massa Lubrense 1991.

${ }^{53}$ Dziejami tego sankturarium zajmował się szerzej dominikanin Michele Miele - zob, Il culto alla Madonna dell'Arco. Contributo alla storia della pietŕ popolare nel napoletano, Napoli 1966, [mps]. s. 511, indeksy; tenże, Le origini della Madonna dell'Arco, Napoli 1995.

${ }^{54}$ Zob. Moroni, Nola, w: Dzionario di erudizione, t. 48, s. 72.

${ }^{55}$ Podaje to relacja z roku 1605 , zob. AV, S. Congr. Concilii Relationes 584A Nolan. f. 494v (dalej ten zespół akt cytuję: AV, Nolan. dołączając rok relacji). W celu uwypuklenia dynamiki wprowadzania reformy trydenckiej w północnych Włoszech dodajmy dla przykładu, że Św. Karol Boromeusz w latach 1565-1581 przeprowadził 11 synodów diecezjalnych i 6 prowincjalnych. W sumie w całym tym regionie odbyło się ponad 100 synodów diecezjalnych i prowincjalnych. Zob. Zagheni, L'etá moderna, s. 195.

${ }^{56}$ Zob. AV, Nolan. 1610, f. 520r.

${ }^{57}$ Zob. AV, Nolan. 1613, f. 512r.

${ }^{58}$ Zob. AV, Nolan. 1610, f. 520r.

${ }^{59}$ Zob. Guadagni, Nola Sagra (1688), s. 107.

${ }^{60}$ Należy jednak zauważyć że Nola czciła aż czterech świętych o tym imieniu: 16 I - san Felice biskupa Tabaloce w Afryce, umęczonego ok. 95 r. w Nola za Domicjana; 9 II - San Felice II, 
ku 366 na grób tego męczennika jako pielgrzym przybył sam papież Damazy. Ponieważ tenże następca św. Piotra polecił powiększyć i upiększyć ów kościół, a także ze względu na szybko rosnącą liczbę wiernych jeszcze w tym stuleciu wzniesiono tam drugą bazylikę. Została ona zorientowana na grób św. Paulina, a poprzez atrium została połączona z poprzednią świątynią ${ }^{61}$.

Dopiero w XIV w., za biskupa Francesco Scaccano (1370-1400) ta swego rodzaju katedra została przeniesiona do centrum miasta Nola. Stało się to na skutek wielkiej liczby pielgrzymów napływających w dniu 16 stycznia do grobu San Felice, co sprawiało że miejsce to urastało bez mała do rangi drugiego Rzymu. Pomimo tego biskupi rezydowali przy owej drugiej bazylice jedynie do roku 1215. Nie mniej dopiero biskup Francesco II Scaccano w roku 1370 otrzymał od papieża Grzegorza XI zgodę na przeniesienie kościoła biskupiego do istniejącej już w Nola świątyni św. Apostołów. Ponieważ kościół ten okazał się niewystarczający, w latach 1395-1475 pięciu kolejnych biskupów kontynuowało dzieło wznoszenia i wyposażania pierwszej katedry miasta $\mathrm{Nola}^{62}$. Niestety w roku 1583 miała miejsce katastrofa - spadło sklepienie katedry, z której pozostały jedynie filary i mury zewnętrzne.

W ten sposób objawia się konieczność zbudowania drugiej katedry. Tym razem dzieło budowy poprowadził dopiero w latach 1596-1614 biskup Fabrizio Gallo, a w latach 1615-1655 wyposażał i nadał tej katedrze pełni splendoru Giovanni Battista Lancellotti. Ta druga katedra pod wezwaniem Matki Bożej Wniebowziętej i Świętych Męczenników Feliksa i Paulina przetrwała jedynie do pożaru wznieconego z motywów politycznych w roku $1861-z o b$. fot. 10a. Była ona krótsza od aktualnie istniejącej katedry (odbudowanej w roku 1898) o dzisiejsze prezbiterium. Została wyposażena, w prezbiterium obok ołtarza głównego posiadała stalle chórowe dla kanoników. Wykonano je w artystyczny sposób $\mathrm{z}$ drzewa orzechowego wraz $\mathrm{z}$ bogatymi intarsjami. W górze, po obu stronach stalli, znajdowały się dwa całkowicie nowe instrumenty organowe (przy czym jeden z nich posiadał znaczą liczbę głosów). Nad ołtarzem głównym istniało łukowe sklepienie bogato ozdobione stiukami i złoconymi promieniami. Na ich tle posród chóru aniołów (wyrzeźbionych w drewnie) dominowała statuła Maryi Wniebowziętej ozdobionej koroną z gwiazd (wykonanych ze srebra). Natomiast po jej obu stronach, w niszach umieszczono statuły świętych - san Felice i Paolino ${ }^{63}$.

Gdy idzie o sieć parafialną tej diecezji to dotychczas pozostaje ona nieokreślona, i to nawet dla pierwszej połowy XVII w. ${ }^{64}$ Możemy tylko stwierdzić, że podstawę źródłową ku temu daje nam już wizytacja biskupia z roku 1551, która to

również biskupa; 16 III - San Felice wyznawcę; i 27 VII - San Felice, kapłana męczennika, który zginął wraz z dwoma dziewicami Gulią i Giocondą. Zob. L. Angelillo, La catedrale di Nola nella sua storia, s. 12.

${ }^{61}$ Zob. tamże, s. 23.

${ }^{62}$ Tamże, s. 15 i 24.

${ }^{63}$ Zob. Angelillo, La catedrale di Nola nella sua storia, s. 26.

${ }^{64}$ Zob. D. de Simone, Brevi notizie intorno alle origini e all'arte nelle varie chiese di Nola, Nola 1931. 
objęła wszystkie tamtejsze kościoły. Najobszerniejsze jednak akta wizytacji biskupiej (zarazem najważniejszej w całym okresie potrydenckim), a przeprowadzonej z wielkim zaangażowaniem i dynamizmem w połowie 1615 roku, dokumentują jej przebieg aż w ponad trzydziestu kościołach, na obszarze dziewięciu miast. Natomiast późniejsze biskupie wizytacje diecezji zrealizowane w roku 1642 posiadają już uwagi na temat 38 kościołów, a w roku 1644 odnośnie 33 kościołów.

Możemy jednak powiedzieć, iż już od XVI w. samo miasto Nola obok katedry miało osiem kościołów. Wśród nich znajdujemy najbliższy katedrze kościół SS.mi Apostoli (istniał od pocz. XIII w., a od 1642 r. był wyłącznie związany z kultem zmarłych) ${ }^{65}$, dalsze to Santa Chiara (z pocz. XIV w.), San Francesco (z k. XIV w.), Il Gesù (budowano go w latach 1568-1578), Santa Maria Nuova, Santo Spirito. Kolejne 3 kościoły parafialne istniały także w pobliskim Cimitile będącym poprzednią siedzibą biskupa (potwierdza to wizytacja biskupa Gallo z 1612 roku) - Mapy 3, 4] ${ }^{66}$.

W Lauro, drugim co ważności mieście tego regionu - spotykamy: kolegiatę Santa Maria Maddalena (1088-1799), kościoły parafialne: San Rocco e San

${ }^{65}$ Zob. G. Remondini, dz. cyt., s. 311; F. Strazzullo, La chiesa dei SS. Apostoli, Napoli 1959; A. M. Russo, La chiesa dei SS. Apostoli in Nola, Napoli 1973; tenże, La chiesa dei SS. Apostoli in Nola. Vicende di un restauro non ancora compiuto, w: Nola e il suo teritorio dalla fine del medio evo al XVII secolo momenti di storia culturale artistica ( Atti del II corso di Formazione per docenti in servizio „Diattica e Teritorio” 10 febbraio - 28 maggio 1994), red. T. R. Toscano, Colanna di testi e studi di storia nolana - Ager Nolanus 5, Distretto Scolastico Nola [Castellammare di Sabia, Somma] 1996, s. 207-213.

${ }^{66}$ Zob. L. Ammirati, Il collegio nolano delle monache rocchettine tra riforma e controriforma, Nola 1988; V. Ampora, I camldoli di Nola - breve descrizione storico artistica, Napoli 1904; L. Avella, La Chiesa del Monastero di S. Chiara in Nola, Nola 1970; D. Bartoli, Compendio della vita e morte del P. Marcello Mastrilli della Compagnia di Gesů (...), Napoli 1671; Bonaventura da Sorento, I cappucini di Nola e Nola serafica. Appunti e note, Napoli 1894; R. Bosel, Jesuitenarchitektur in Italien 1540-1773. Die Baudenkmaler der romanischen und der neapolitanischen Ordenprovinz, Wien 1985' Bove - Verrengia - Malgnini, Il convento di S. Francesco in Nola (oggi S. Biagio), Nola 1980; D. Capolongo, Pietro Manzi. Commemorazione, „Il Cittadino”, 4 (1983); Simone, Brevi notizie intorno alle origini e all'arte nelle varie chiese di Nola; F. G. Goffredo, Vita del venerabile P. Marcello Mastrilli della Compagnia di Gesü, Napoli 1910; F. Iapelli, Gesuiti a Nola: 1588-1767, „Societas”, 1-2 (1992) s. 20-35; P. Manzi, La Chiesa del Gesů di Nola, „Palestara”, 1-5 (1966); tenże, Il monastero e la chiesa di S. Francesco di Paola in Cimitile, Roma 1959 oraz La reggia degli Orsini (1470-1970), Roma 1971, s. 48-58; G. Mollo, Il Convento di S. Angelo in Palco a Nola. Appunti di ricerca, w: Didattica e Teritorio (Corso di formazione per docenti in servizio, 30 marzo - 8 giugno 1988), XXX Distretto Scolastico - Nola, [Nola 1990], s. 215-223; A. M. Russo, La chiesa dei SS. Apostoli in Nola, Napoli 1973; tenże, La chiesa dei SS. Apostoli in Nola. Vicende di un restauro non ancora compiuto, w: Nola e il suo teritorio dalla fine del medio evo al XVII secolo momenti di storia culturale artistica (Atti del II corso di Formazione per docenti in servizio "Diattica e Teritorio" 10 febbraio - 28 maggio 1994), red. T. R. Toscano, Colanna di testi e studi di storia nolana - Ager Nolanus 5, Distretto Scolastico Nola [Castellammare di Sabia, Somma] 1996, s. 207-213; M. Zampino, La Chiesa vecchia di S. Chiara in Nola, w: "Atti del V Convegno nazionale di storia dell'achitettura" Perugia 1948, s. 437-450. 
Sebastiano, San Barbato za murami miasta (wzn. w śred.) ${ }^{67}$ i Santa Maria della Pietŕ (wzn. XIV/XV w.) ${ }^{68}$, a także klasztor augustianów przy kościele Santa Maria della Strada (spalony w 1799 roku), i kościół Sant Angelo przy rezydencji opata bendyktynów z Taurano (zał. ok. 1087 roku), franciszkański i kościół San Giovanni in Palco (wzn. 1383) ${ }^{69}$, a wreszcie dwa klasztory żenskie: Gesů e Maria (eryg. ok. 1460) i Santa Trinitŕ (ok. 1615-1799) ${ }^{70}$.

\section{Bibliografia}

Z myślą o efektywnej realizacji wspomnianych powyżej tematów badawczych prezentujemy stosunkowo liczną bibliografię (ponad 180 tytułów artykułów i książek) opublikowanych od połowy XVII w. do czasów współczesnych. Ich autorzy zajmują się zarówno historią poszczególnych miast tego regionu, jak też dziejami rodzin książęcych, nobilitowanych oraz historią zakonów, instytucji i działalnością najwybitniejszych osobistości. Nie zabrakło tu także prac z zakresu historii kultury i sztuki.

Accolito G., Vita del Venerabile Padre Marcello Francesco Mastrilli, della Compagnia di Gesü, martire nel Giappone, Monza 1990.

Acta Nuntiaturae Polonae, t. 22: Giovanni Battista Lancellotti (1622-1627), vol. 1: (22 XI 1622 - 31 XII 1623) in quo publicantur etiam documenta internuntii Antonii Francisci Cirioli (12 XI 1622 -29 IV 1623), ed. T. Fitych, Academia Scientiarum et Litterarum Polona (Sumptibus Fundationis Lanckoroński), Cracoviae 2001, LXIV, 381 [n. t. diec. Nola zob. s. V-XXIV].

Aldimari B., Memorie istoriche di diverse famiglie nobili, cosě napoletane come forestiere (...), Napoli 1651.

Alisio G., Il palazzo ducale di Palma Campagnia, Napoli 1971.

Amagiá R., Studi storici di cartografia napoletana, „Archivio storico per le province napoletane", 37 (1913) s. 318-319.

Ambrosini A., Delle memorie storico-critiche del Cimitero di Nola, Napoli 1792.

Ammirati L., Nola nella luce della Rinascenza, Nola 1980.

Ammirati L., Ambrogio Leone nolano, Marigliano 1983.

Ammirati L., Il collegio nolano delle monache rocchettine tra riforma e controriforma, Nola 1988.

Ammirati L., Il giglio č sinonimo di Nola, „Opinione” II, 13, 1960 Nola.

AA.VV., Storia della Campagna, red. F. Barbagallo, Napoli 1978.

AA. VV., Nola cittá millenaria, red. G. Minieri, Nola 1981;

Ampora V., I camaldoli di Nola - breve descrizione storico artistica, Napoli 1904;

${ }^{67}$ Zob. P. Moschiano, La terra di Lauro nei secoli. Sintesi storica, w: Didattica e Teritorio (Corso di formazione per docenti in servizio, 30marzo - 8 giugno 1988), XXX Distretto Scolastico - Nola, [Nola 1990], s. 113-118.

${ }^{68}$ Zob. P. Moschiano, La chiesa di Santa Maria della Pietŕ in Lauro, Marigliano 1989.

${ }^{69}$ Zob. G. Mollo, Il Convento di S. Angelo in Palco a Nola. Appunti di ricerca, w: Didattica e Teritorio (Corso di formazione per docenti in servizio, 30 marzo - 8 giugno 1988), XXX Distretto Scolastico - Nola, [Nola 1990], s. 215-223.

${ }^{70}$ Zob. P. Moschiano, 1799 - Saccheggio e incendio di Lauro, Lauro 1979, s. 67 -79. 
Andretta S., Le nunziature in Italia nei secoli XVI e XVII, w: Kurie und Politik. Stand und Perspektiven der Nuntiaturberichtsforschung, Hrsg. Alexander Koller (Sonder druck aus: Bibliothek des Deutschen Historischen Instituts in Rom Bd. 87), Tübingen 1998, s.17-34;

Angelillo L., La catedrale di Nola nella sua storia, Napoli 1909.

Avella L., Casate presenti nella cittŕ di Nola tra il secolo XV e il secolo XVIII, Napoli 1979.

Avella L., La festa dei Gigli dalle origini ai nostri giorni, Nola 1979.

Avella L., Presentazione di una copia manoscritta inedita relativa ai confini territoriali della cittá di Nola nel 1639 con i suoi casali (...), Napoli 1977.

Avella L., La Chiesa del Monastero di S. Chiara in Nola, Nola 1970.

Avella L., Le tavole di bronzo della cittá di Nola, Nola 1970.

Avella L., Nola ipotesi 2, Napoli 1970.

Avella L., Presentazione di una copia manoscritta inedita relativa di confini territoriali della cittá di Nola nel 1639 - LER, Napoli 1977.

Bartoli D., Compendio della vita e morte del P. Marcello Mastrilli della Compagnia di Gesů (...), Napoli 1671.

Battista P., Folklore campano. La Sagra dei «Gigli», Firenze 1973.

Beltrano O., Breve descrizione del Regno di Napoli diviso in dodeci provincie, Napoli 1644; 1671; reprint Forni 1983.

Beradesca A., Historia di santo Felice martire et episcopio di Nola [1560], w: Nola e il suo teritorio, red. T. R. Toscano, Colanna di testi e studi di storia nolana - Ager Nolanus 3, Distretto Scolastico Nola [Castellammare di Sabia, Somma] 1994.

Berti D., Documenti intorno a Giordano Bruno da Nola, Roma 1880.

Bifulco G., Lauro e il suo Vallo attraverso i secoli, [Somma Vesuviana] 1986.

Bonaventura da Sorento, I cappucini di Nola e Nola serafica. Appunti e note, Napoli 1894;

Bosel R., Jesuitenarchitektur in Italien 1540-1773. Die Baudenkmaler der romanischen und der neapolitanischen Ordenprovinz, Wien $1985^{2}$.

Bove - Verrengia - Malgnini, Il convento di S. Francesco in Nola (oggi S. Biagio), Nola 1980.

Braccini G. C., Dell'incendio fattosi nel Vesuvio a 16 di dicembre 1631 e delle sue cause ed efetti, Napoli 1632.

Buonfiglio G., Il convento di San Giovanni del Palco in Tauro, w: Nola e il suo teritorio dalla fine del medio evo al XVII secolo momenti di storia culturale e artistica (Atti del II corso di Formazione per docenti in servizio "Diattica e Teritorio" 10 febbraio - 28 maggio 1994), red. T. R. Toscano, Colanna di testi e studi di storia nolana - Ager Nolanus 5, Distretto Scolastico Nola [Castellammare di Sabia, Somma] 1996, s. 225 242 ;

Caccavale A., La compagnia di Gesů: Fede e cultura a Nola dalle origini alla soppressione, (Tesi discussa presso l'Isituto Superiore di Scienze Religiose di Nola nell' a. 19901991);

Ciazzo C., Pomigliano d'Arco nella sua storia, Napoli 1966.

Campanelli D., Toscano G., Il patrionio storico-artistico delle chiese di Roccarainola, Roccarainola 1983;

Candida Gonzaga B., Memorie delle famiglie nobili delle province meridionali d'Italia, Napoli $1875-1883^{6}$.

Cantone S., Cenni storici di Pomigliano d'Arco, Nola 1923.

Capelletti A., Guerrieri e mistici in Nola medievale, Nola 1991; Panettiere². 
Capolongo D., Beni culturali e ambientali in teritorio di Roccaraindola, Roccaraindola 1975.

Capolongo D., Nola, l'Agro e Cicciano, Marigliano 1979.

Capolongo D., Pietro Manzi. Commemorazione, „Il Cittadino”, 4 (1983).

Capolongo D., Regesti delle antiche pergamene dell'Archivio Capitolare della Cattedrale di Nola, w: Atti del Circolo Culturale B. G. Scoto di Roccaraindola, 16-17, Roccaraindola 1991, s. 41-136.

Carillo S., Alcune osservazioni sulla pianta della cittá allegata al De Nola di Ambrogio Leone, w: Nola e il suo teritorio dalla fine del medio evo al XVII secolo momenti di storia culturale e artistica (Atti del II corso di Formazione per docenti in servizio "Diattica e Teritorio" 10 febbraio - 28 maggio 1994), red. T. R. Toscano, Colanna di testi e studi di storia nolana-Ager Nolanus 5, Distretto Scolastico Nola [Castellammare di Sabia, Somma] 1996, s. 25-43;

Carillo S., La Cittá attorno alla cattedrale (Il restauro del Duomo di Nola e la sua influenza sull 'assetto urbano, a cura dei Maestri di Festa della Corporazione dei Panettieri - Nola, [Nola] Festa dei Gigli 1989.

Carillo S., La ricostruzione del Duomo di Nola: 1861-1909, w: Tutela e restauro dei monumenti in Campania 1860-1900, red. G. Fiengo, Napoli 1993, s. 399-412;

Cola S., S. Giuseppe Vesuviano nella storia e le piů famose eruzioni del Vesuvio, S. Giuseppe Vesuviano 1892;

Comparato, V. U., Uffici e societá a Napoli (1600-1647). Aspetti dell'ideologia del magistrato nell' etŕ moderna (biblioteca dell'Archivio Storico Italiano, XIX), Firenze 1974 ;

Cortese N., Feudi e feudatari napoletani nella prima metá del cinquecento, „Archivio Storico per le provinze napoletane", seria II, t. 54 (1929);

Ciro Rubino, Storia di Nola, 1991;

Colletta P., Storia del Reame di Napoli, a cura di N. Cortese, Napoli 1957³;

Crollalanza, Gio.B. di, Dizionario storico-blasonico delle famiglie nobili e notabili italiane, 3 voll. Pisa 1886-1890; reprint Forni 1977;

Di Costanzo A., Historia del Regno di Napoli, Napoli 1792;

D'Andrea G., I Frati Minori napoletani nel loro sviluppo storico, Napoli 1967;

D’Ascoli F., Ottaviano: terra di Augusto, Napoli 1985;

D’Avanzo L., Cimitile celebre dopo Roma, Nola 1931;

D’Avanzo L., Memorie storiche di Roccarainola, Nola 1943;

De Simone D., Brevi notizie intorno alle origini e all'arte nelle varie chiese di Nola, Nola 1931;

AA., Didattica e Teritorio (Corso di formazione per docenti in servizio, 30marzo - 8 giugno 1988), XXX Distretto Scolastico - Nola, [Nola 1990];

Di Montanara G. B., Le famiglie 'egregie'di Nola nel primo decennio del secolo decimosesto, „Rivista araldica”, 58 (1960) nr 5, s. 185-190;

Diocesi di Nola. Annuario della Chiesa di Nola, [Castellammare di Sabia, Somma] 1985

D’Onofrio P. A., Il Santuario Maria SS. del Carpinello in Visciano di Nola, [b.m.w.] 1936;

Errichetti B., L'antico Colleggio dei Gesuiti a Napoli, „Campagna Sacra”, 7 (1976) s. 170264;

Fiengo G., La chiesa e il convento di S. Maria del Pozzo a Somma Vesuviano, „Napoli Nobilissima", 4 (1964) s. 125-132;

Ferraro A., Cemeterio Nolano, Napoli 1644, s. 73-88; 
Fiengo G., Progetti e realizzazioni per il risanamento e lo sviluppo di Napoli e la bonifica di Terra di Lavoro 1592-1631, w: Nola e il suo teritorio dalla fine del medio evo al XVII secolo momenti di storia culturale e artistica (Atti del III corso di Formazione per docenti in servizio “Diattica e Teritorio"), red. T. R. Toscano, Colanna di testi e studi di storia nolana - Ager Nolanus 5, Distretto Scolastico Nola [Castellammare di Sabia, Somma] 1998, s. 1-18;

Fitych T., Herb rodziny Lancellottich oraz jej przedstawiciela Jana Chrzciciela Lancellotti - nuncjusza apostolskiego w Polsce (1622 - 1627), „Saeculum Christianum”, 1 (1994) nr 1, s. 161-172;

Fitych T., Kariera kurialna i dyplomatyczna do roku 1614 Giovanniego Battisty Lancellottiego nuncjusza apostolskiego w Polsce w latach 1622-1627, w: Stowo nieskowane, Księga Jubileuszowa dla ks. Jana Kruciny, red. A. Nowicki, J. Tyrawa, Wrocław 1998, s. 661-672;

Fitych T., Diecezja Nola w latach 1615-1655. Rzady biskupa Giovanniego Battisty Lancellottiego nuncjusza apostolskiego w Polsce (1622-1627), „Studia TeologicznoHistoryczne Śląska Opolskiego", 19 (1999) s. 135-171;

Fitych T., Krag rodzinny Giovanniego Battisty Lancellottiego, 31-szego nuncjusza apostolskiego w Polsce, ,Roczniki Teologiczne KUL”, 47 (2000) z. 4, s. 81-112;

Fitych T., Pół wieku służby Kościołowi Giovanniego Battisty Lancellottiego - nuncjusza apostolskiego w Polsce (1622-1627), „Saeculum Christianum”, 7 (2000) nr 2, s. $67-$ 90 ;

Fitych T., Osobowość i prestiż prałata Giovanniego Battisty Lancellottiego nuncjusza apostolskiego $w$ Polsce (1622-1627), „Studia Teologiczno-Historyczne Śląska Opolskiego", 20 (2000) s. 299-330;

Fitych T., Inizi della missione diplomatica di Giovanni Battista Lancellotti- nunzio apostolico in Polonia (1622-1627), „Lateranum”, 67 (2001) fasc. 1, s.71-111

Fitych T., Włoska działalność Giovanniego Battisty Lancellottiego, „Studia Warmińskie”, 38 (2001) s.117-138;

Foglia M., Visciano. Fede - Storia - Arte, Napoli - Roma [Girgensohn Dieter, "Nola”, w: LThK $^{2}$, t. 7, Freiburg 1986, 1019;

Galaso G., Napoli nel Viceregno Spagnolo dal 1648 al 1696, w: Storia di Napoli, vol. 6, t. 1, Napoli 1970, s. 1-400;

Galasso G., Alla periferia dell'impero. Il Regno di Napoli nel periodo spagnolo (secoli XVI-XVII), Torino 1994;

Giordano S., Le istruzioni generali di Paolo $V$ ai diplomatici pontifici 1605-1621, t. 2, Tübingen 2003, nr 39 i 80, s. 605-611, 1006-1013;

Giuliano S., La Chiesa cattedrale e i Vescovi di Nola attraverso la Storia (Brevi notizie desunte dall'opere di Mons. Angelillo), Nola [1979];

Giustiniani L., Dizionario geografico-ragionato del Regno di Napoli, Napoli 1804$1805^{10}$

Gleijeses V., Castelli in Campagnia, Napoli 1973²;

Goffredo F. G., Vita del venerabile P. Marcello Mastrilli della Compagnia di Gesů, Napoli 1910 ;

Guadagni C., Nola Sagra (1688), red. T. R. Toscano, Massa Lubrense 1991;

Iannelli G., Brevi cenni degli scrittori ed uomini illustri della cittá di Nola e di quelli si occuparono della medesima cittá, Caserta 1888;

Iapelli F., Gesuiti a Nola: 1588-1767, „Societas”, (1992), nr 1-2, s. 20-35;

Imhoff A., Genealogiae viginti illustrium in Italia familiarum..., Amsteledami 1710;

Itinerari de l'Espresso, Napoli e la Campania, Vincenza 1980; 
Koch L., Jesuitenlexikon - Die Gesellschaft Jesu einst und jetzt, Bd. 1-2, Löven-Héverlé 1962 ;

Lauro A., Il Giurisdizionalismo pregannoniano nel Regno di Napoli. Problema e Bibliografia (1563-1723) (Sussidi eruditi, 27), Roma 1974;

Laurino A., Saggio di Bibliografia Nolana, Nola 1988;

Leone A., Nola (la terra natia), trad. di P. Barbati, Napoli 1934;

Leclerq H., Nole, w: Dictionaire d'archéologie chréteienne et de liturgie, publié par F. Garol e H. Leclerq, t. 12, Paris. 1936, k. 1422-1465;

Lellis C. de, Discorsi delle famiglie nobili del Regno di Napoli, 3 Voll. Napoli 1654, 1663, 1671; reprint Forni 1968 pod tytułem: Famiglie nobili del Regno di Napoli;

Luca F. Renato de, Vescovi di Nola appartenenti alla nobiltá, „Rivista Araldica”, 77 (1979) nr 7, s. 144-147;

Luca F. Renato de, L'Archivio Storico Diocesano di Nola, w: Nola e il suo teritorio dalla fine del medio evo al XVII secolo momenti di storia culturale e artistica (Atti del III corso di Formazione per docenti in servizio “Diattica e Teritorio”), red. T. R. Toscano, Colanna di testi e studi di storia nolana - Ager Nolanus 5, Distretto Scolastico Nola [Castellammare di Sabia, Somma] 1998, s. 245-251;

Luca F. R. de, La tradizione paolina attraverso Le Sante Visite dei Vescovi di Nola, „Bollettino diocesano nolano”, VIII, 3, Nola 1979, s. 199-204;

Maione G., Mariglianella nella Storia (alla riscoperta di un paese: figure ed eventi di ieri e di oggi), [Brusciano 1995];

Manganelli F., La sagra dei 'Gigli' a Nola, Napoli 1966;

Manzi P., Il Castello di Cicala nella storia di Nola, wyd. Paolo, Nola 1973;

Manzi P., Il Castello di Roccarainola nel quadro dei castelli del Regno di Napoli, Roma 1964;

Manzi P., La Chiesa del Gesů di Nola, in „Palestara”, nr. 1-5, Maddaloni Caserta 1966;

Manzi P., Gian Stefano Remondini (1700-1777). La vita e le opere, Rapallo 1958;

Manzi P., Il monastero e la chiesa di S. Francesco di Paola in Cimitile, Roma 1959;

Manzi P., Sopra alcuni documenti di cartografia nolana, ovvero Ambrogio Lone e Gerolamo Moceto, „Opinione”, (1962), nr 1-2; Firenze 1973 (nadb.);

Manzi P., La reggia degli Orsini (1470-1970), Roma 1971;

Mascia V. G., Confraternite francescane a Napoli in una Cronaca inedita del Seicento, Napoli 1979;

Mazzarelli G., Culto a Maria SS. Addolorata in Roccainola. Cenni storici, Nola 1929;

Mazzella S., Descrittione del Regno di Napoli, Napoli 1601; reprint Forni 1981;

Meo F., Visciano, storia, leggenda folclore, Napoli 1977;

Miele M., La riforma domenicana a Napoli nel periodo post-tridentino (1583-1725), Roma 1963;

Miele M., Die Provinzialkonzilien Süditaliens in der Neuzeit, Konziliengeschichte, wyd. W. Brandmüller, A. Reihe: Darstellungen, Padeborn 1996;

Miele M., Il culto alla Madonna dell'Arco. Contributo alla storia della pietŕ popolare nel napoletano, Napoli 1966, ss. 511, indeksy [mps];

Miele M., Le origini della Madonna dell'Arco, Napoli 1995;

Miele M., Ricerche sulla oppressione dei religiosi nel Regno di Napoli, „Campagna Sacra", 4 (1973);

Minieri A., Compendio della Terra di Nola, Nola 1973;

Minieri A., Storia di Nola dalle origini ai nostri giorni, Nola 1983;

Minieri Riccio C., Notizie biografiche e bibliografiche degli scrittori napoletani fioriti nel secolo XVII, Milano 1875-1877; 
Mollo G., Il Convento di S. Angelo in Palco a Nola. Appunti di ricerca, w: Didattica e Teritorio (Corso di formazione per docenti in servizio, 30 marzo - 8 giugno 1988), XXX Distretto Scolastico - Nola, [Nola 1990], s. 215-223;

Mollo G., La chiesa di Santa Chiara in Nola. Contributo per un'analisi storico-architettonica, w: Nola e il suo teritorio dalla fine del medio evo al XVII secolo momenti di storia culturale e artistica (Atti del III corso di Formazione per docenti in servizio "Diattica e Teritorio"), red. T. R. Toscano, Colanna di testi e studi di storia nolana Ager Nolanus 5, Distretto Scolastico Nola [Castellammare di Sabia, Somma] 1998, s. 109-119;

Mollo G., Relazioni culturali tra Orsini e Aragonesi (1436-1459), e un'indagine su due affreschi inediti nel Convento di San Angelo in Palco a Nola, w: Atti del III Convegno dei Gruppi Archeologici della Campagnia, Nola 1982;

Moschiano P., La terra di Lauro nei secoli. Sintesi storica, w: Didattica e Teritorio (Corso di formazione per docenti in servizio, 30 marzo - 8 giugno 1988), XXX Distretto Scolastico - Nola, [Nola 1990], s. 107-124;

Moschiano P., Lauro: il castello e due cicli pittorici, w: Nola e il suo teritorio dalla fine del medio evo al XVII secolo momenti di storia culturale e artistica (Atti del II corso di Formazione per docenti in servizio "Diattica e Teritorio" 10 febbraio - 28 maggio 1994), red. T. R. Toscano, Colanna di testi e studi di storia nolana - Ager Nolanus 5, Distretto Scolastico Nola [Castellammare di Sabia, Somma] 1996, s. 177-193;

Moschiano P., Lauro e il Vallo nella rivoluzione del 1799, w: Nola e il suo teritorio dalla fine del medio evo al XVII secolo momenti di storia culturale e artistica (Atti del III corso di Formazione per docenti in servizio ,,Diattica e Teritorio”), red. T. R. Toscano, Colanna di testi e studi di storia nolana - Ager Nolanus 5, Distretto Scolastico Nola [Castellammare di Sabia, Somma] 1998;

Moschiano P., La chiesa di Santa Maria della Pietá in Lauro, Marigliano 1989;

Moschiano P., 1799 - Saccheggio e incendio di Lauro, Lauro 1979;

Moschiano P., Il Santuario della Madonna della Caritá, Marigliano 1972;

Moschiano P., Vallo di Lauro e Castello Lancellotti, Guida turistica, Marigliano 1971;

Muscco A., Nola e dintorni, Napoli 1934;

Nola - hasła encyklopedyczne, m.in. w: Annuario Pontificio, Cittá del Vaticano 1993, s. 474; Enciclopedia Cattolica, t. 8, k. 1912-1916; Enciclopedia Italiana di scienze, lelere ed arti, t. 25, Roma 1950, s. 887-888; Grande Dizionario Enciclopedico, t. 14, [Torino 19894], s. 601; LfThK, t. 7, Friburg 1962, k. 1019;

Nola e il suo teritorio dalla fine del medio evo al XVII secolo momenti di storia culturale e artistica (Atti del II corso di Formazione per docenti in servizio "Diattica e Teritorio" 10 febbraio - 28 maggio 1994), red. T. R. Toscano, Colanna di testi e studi di storia nolana - Ager Nolanus 5, Distretto Scolastico Nola [Castellammare di Sabia, Somma] 1996;

Nola e il suo teritorio dalla fine del medio evo al XVII secolo momenti di storia culturale $e$ artistica (Atti del III corso di Formazione per docenti in servizio "Diattica $e$ Teritorio"), red. T. R. Toscano, Colanna di testi e studi di storia nolana-Ager Nolanus 5, Distretto Scolastico Nola [Castellammare di Sabia, Somma] 1998;

Padre Antonio di Nola, Cronaca francescana della riformata Provincia di Napoli detta Terra di Lavoro, Napoli 1718;

Pacichelli G. B., Il Regno i Napoli in prospettiva, t. 1-3, Napoli 1702-3

Palliola F., La reggia degli Orsini di Nola, w: Partito Repubblicano Italiano. Sezione di Nola e Piazzola. Impegno del Partito per la cittá di Nola, [Castellammare di Sabia, Somma] Convegno del 18 marzo 1986; 
Pane R., Il Rinascimento nell'Italia meridionale, t. 1, Milano 1975;

Pluco G., Storia Storia del monachesimo in Italia, t. 1, Roma 1961;

Pro Loco Taurano, Convento di S. Giovanni del Palco, quida storica-artistica, Domicella 1986;

Remondini Gianstefano, Della Nolana Ecclesiastica storia, t. 3, Napoli 1757;

Riccio L., Nuovi documenti sull'incendio vesuviano del 1631, Archivio Storico Province Napoletane, 14, Napoli 1889;

Ricciardi R., Marigliano ed i comuni del suo mandamento, Napoli 1893;

Romanelli D., Antica topografica istorica del Regno di Napoli, Napoli 1815-18193;

Romano A., Il Teritorio nolano nella storia, 1988;

Rubino Ciro, Storia di Nola, Napoli 1991;

Russo A. M., La chiesa dei SS. Apostoli in Nola, Napoli 1973;

Russo A. M., La chiesa dei SS. Apostoli in Nola. Vicende di un restauro non ancora compiuto, w: Nola e il suo teritorio dalla fine del medio evo al XVII secolo momenti di storia culturale artistica (Atti del II corso di Formazione per docenti in servizio "Diattica e Teritorio" 10 febbraio - 28 maggio 1994), red. T. R. Toscano, Colanna di testi estudi di storia nolana-Ager Nolanus 5, Distretto Scolastico Nola [Castellammare di Sabia, Somma] 1996, s. 207-213;

Sacco F., Dizionario geografico-istorico-fisico del Regno di Napoli, Napoli 1796;

Santoro L., Castelli angioni e aragonesi nel Regno di Napoli, a cura di T. Pedio, Galatina 1972;

Saviano L., La cittá di Ottaviano. Origine e storia, Napoli 1968;

Scandone F., Documenti per la storia dei Comuni dell'Irpinia, Lauro e Casali, t. 3 Napoli 1983;

Schinosi F., Istoria della Compagnia di Gesů appartenente al Regno di Napoli, Napoli 1706-17112;

Spampanato V., Vita di Giordano Bruno con documenti editi e inediti, Messina 1921, (edizione anasatica con postfazione di N. Ordine, Roma 1988);

Storia di Avvelino, t. 3, Avvelino - Napoli 1947-1950;

Strafforello G., La Patria. Geografia dell'Italia. Provincia di Avvelino, Benevento, Caserta, Salerno, Torino 1898;

Strazzullo F., La chiesa dei SS. Apostoli, Napoli 1959

Summonte G. A., Historia della Cittá e Regno di Napoli, t. 1- 2 Napoli 1592-1602;

Toscano T. R., L'Ager Nolanus nella storiografia nolana tra Cinquecento e Settecento, $1-7 ; 2$

Toscano T. R., Il De Nola Ambrogio Leone: sogno e nostalgie di una capitale del Rinascimento, w: Nola e il suo teritorio dalla fine del medio evo al XVII secolo momenti di storia culturale e artistica (Atti del II corso di Formazione per docenti in servizio "Diattica e Teritorio" 10 febbraio - 28 maggio 1994), red. T. R. Toscano, Colanna di testi e studi di storia nolana - Ager Nolanus 5, Distretto Scolastico Nola [Castellammare di Sabia, Somma] 1996, s.19-23;

Toscano T. R., Gianstefano Remondini (1700-1777) accademico e polemista (con inediti), w: Studi in onore di Pietro Manzi, Rocarainola 1983, s. 61-153;

Toscano T. R., Il Seminario della discordia: un'inedita 'cronaca” di Gianstefano Remondini sull'ostilitá dei nobili nolani ai progetti di Troiano Caracciolo del Sole, w: Nola e il suo teritorio dalla fine del medio evo al XVII secolo momenti di storia culturale e artistica (Atti del III corso di Formazione per docenti in servizio "Diattica e Teritorio"), red. T. R. Toscano, Colanna di testi e studi di storia nolana-Ager Nolanus 5, Distretto Scolastico Nola [Castellammare di Sabia, Somma] 1998, s. 19-56; 
Trinchese G., Il duomo di Nola, Nola 1909;

Turboli T., Ricerche storiche su di Marigliano e Pomigliano d'Arco, Napoli 1794;

Ughelli F., Italia sacra sive de episcopis Italiae et insularum adiacenttium, Roma 1662², Venezia 1717-1722 el.;

Quindici V., La Signoria degli Orsini a Nola (1290-1533), w: Nola e il suo teritorio dalla fine del medio evo al XVII secolo momenti di storia culturale e artistica (Atti del II corso di Formazione per docenti in servizio "Diattica e Teritorio" 10 febbraio - 28 maggio 1994), red. T. R. Toscano, Colanna di testi e studi di storia nolana - Ager Nolanus 5, Distretto Scolastico Nola [Castellammare di Sabia, Somma] 1996, s. 9-18;

Vincenti G., La Contea di Nola dal secolo XIII al XVI, Napoli 1987;

Zampino M., La Chiesa vecchia di S. Chiara in Nola, w: Atti del V Convegno nazionale di storia dell'achitettura, Perugia 1948, s. 437-450;

Zenobi, B. G., Da Ferrara a Benevento: i moduli del potere oligarchico tra basso medioevo ed etŕ barocca, w: Studi Urbinati, N.S. A 35-37, anni 51-53(1982-1985, wydano 1988), s. 7-25;

Zigarelli G., Storia della cattedra di Avellino e de' suoi Pastori, Napoli 1856²;

Zigarelli G., Storia di Benevento, Napoli 1860.

\section{INTRODUCTION TO STUDIES OVER DIOCESE NOLA IN THE $17^{\text {th }}$ CENTURY}

Summary

The author is known in Poland by his many works, as, for example, the history and organization the Polish Nuncio's office, and the history, the culture and theology of Silesia. He also promises to extend his research into the implementation of the reform resolutions of the Council of Trent in the diocese of Nola, one of the most prestigious dioceses in Italy. The origins of this diocese coincide with the very origins of Christianity.

Keeping in mind the vitality of that work as well as desiring to eliminate the gap caused by a lack of a monograph on the history of that local Church, the author presents both a brief overview of the history of the region, of Naples and the diocese of Nola itself, presenting its best known rulers, the history of the basilicas and bishop's churches, as well as the state of the parishes until the early years of seventeenth century.

To this end, the author has compiled a lengthy bibliography (over 180 titles of books and articles) published between the middle of seventeenth century and now. These works deal with the history of this region's towns, its royal and ennobled houses, and also with its religious orders, institutions and most outstanding persons. Works from the areas of culture and art are also considered. 


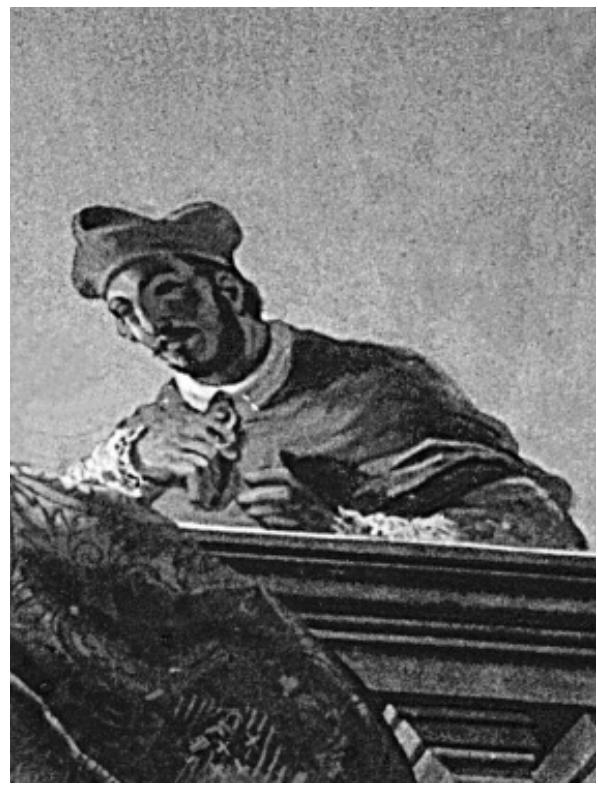

Fot. 1. Nuncjusz Giovanni Battista Lancellotti

Fresk w willi Lancellottich we Frascati koło Rzymu wykonany przez Domenico Forti w latach 1873-1884

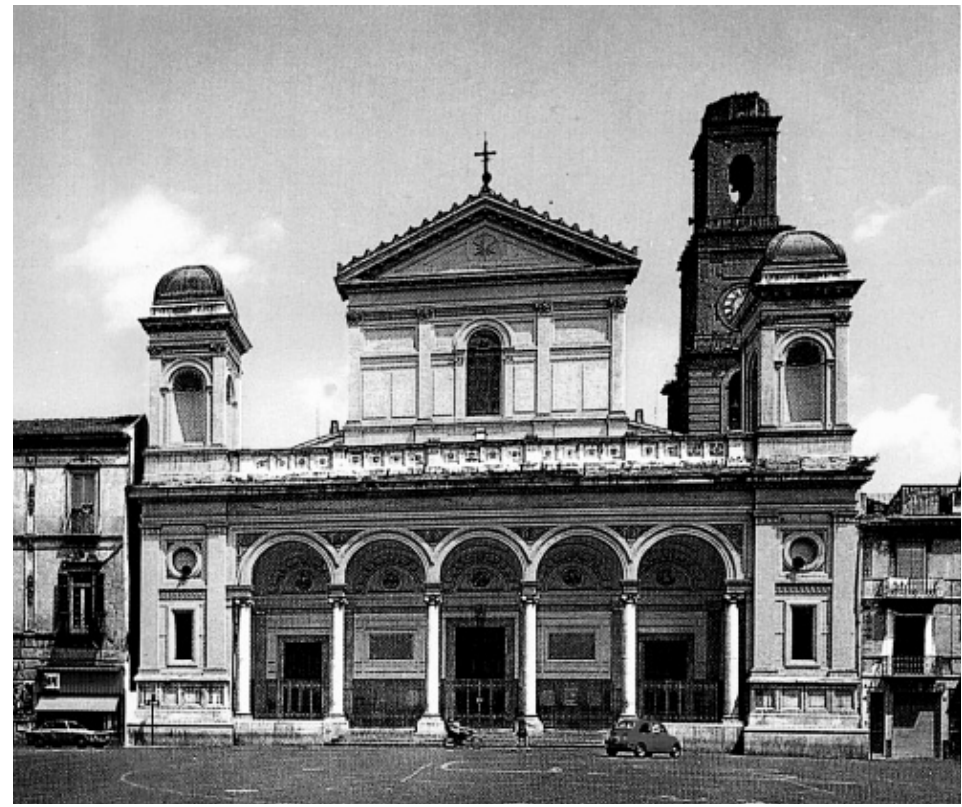

Fot. 2. Nola - katedra

(trzecia z kolei budowla katedry Matki Bożej Wniebowziętej i Św. Męcz. Feliksa i Paulina, przebudowana w poł. XVII wieku i odbudowana po pożarze w 1898 roku) 


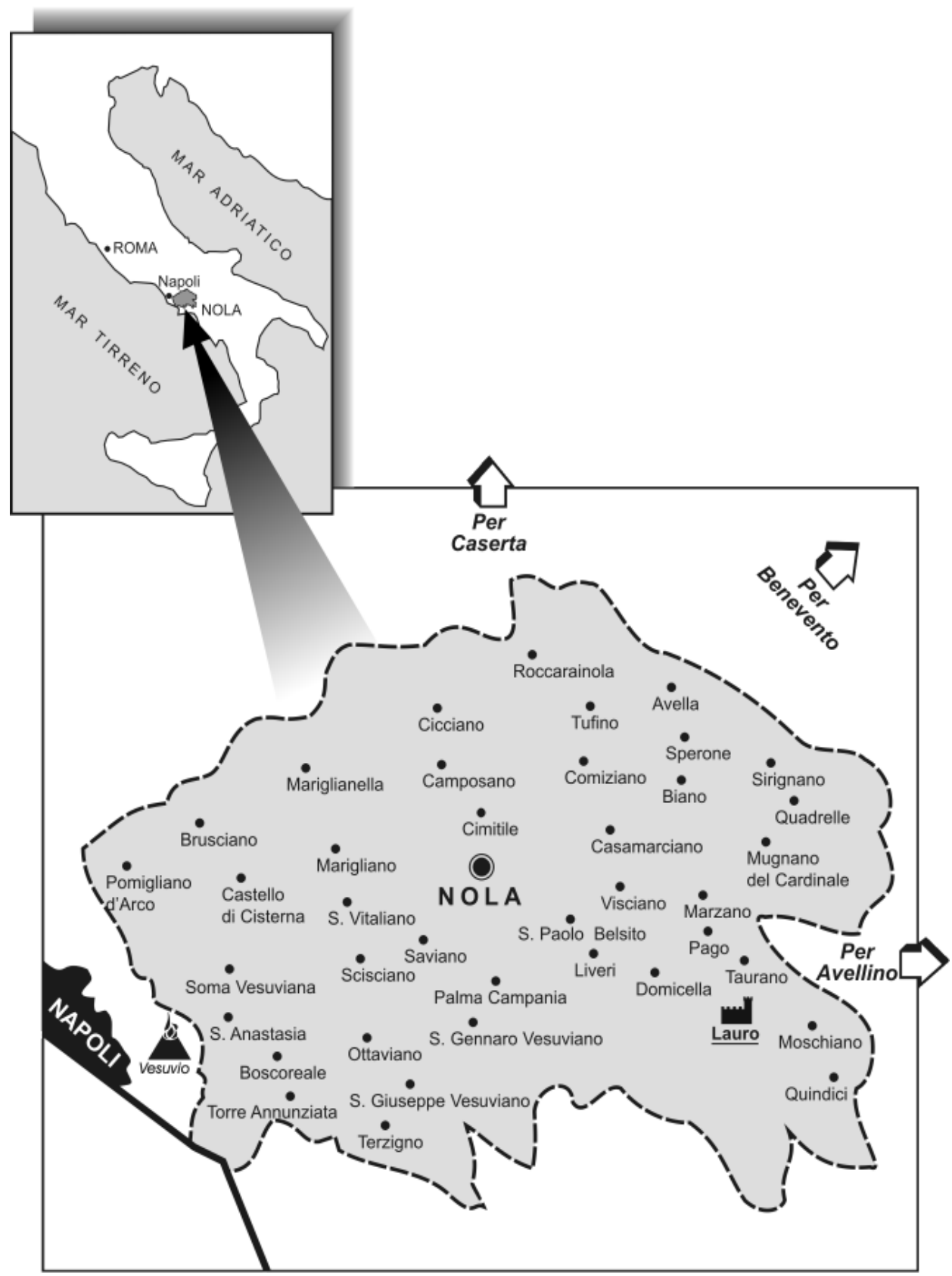

\section{Mapa 1. Przybliżone granice diecezji Nola w XVII wieku}

Odtworzono na podstawie stanu z 1492 roku opisanego przez Ambrogio Leone, De Nola Patria, Venezia 1514, lib. 1, cap. 10, a znowelizowano w oparciu o dane zaczerpnięte $\mathrm{z}$ siedemnastowiecznych relacji biskupicyh 


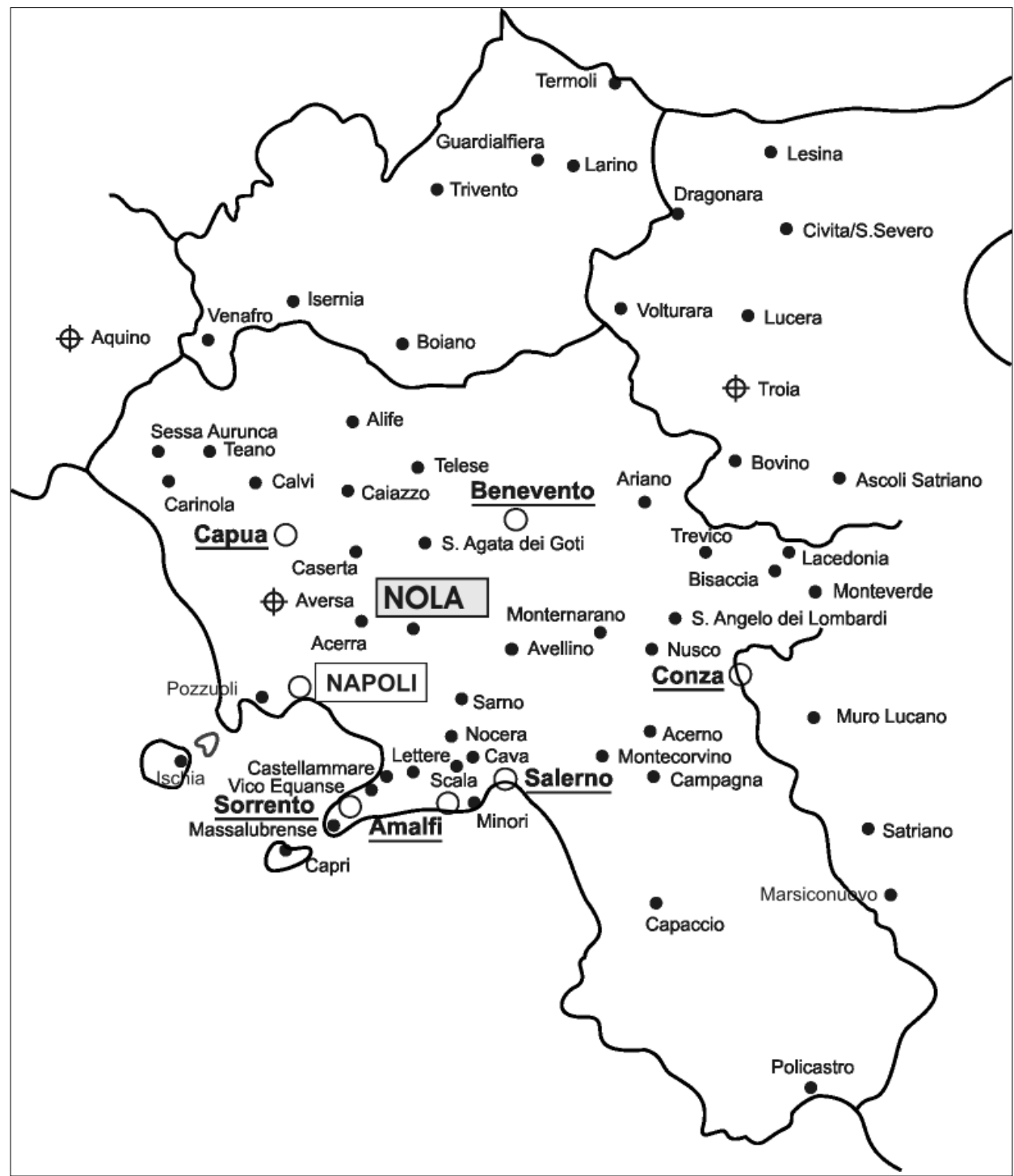

- siedziby metroloplii

○ siedziby diecezji

$\oplus$ diecezje bezpośrednio zależne od Kurii Rzymskiej

Mapa 2. Sieć metropolii i diecezji w Kampanii w XVII wieku 


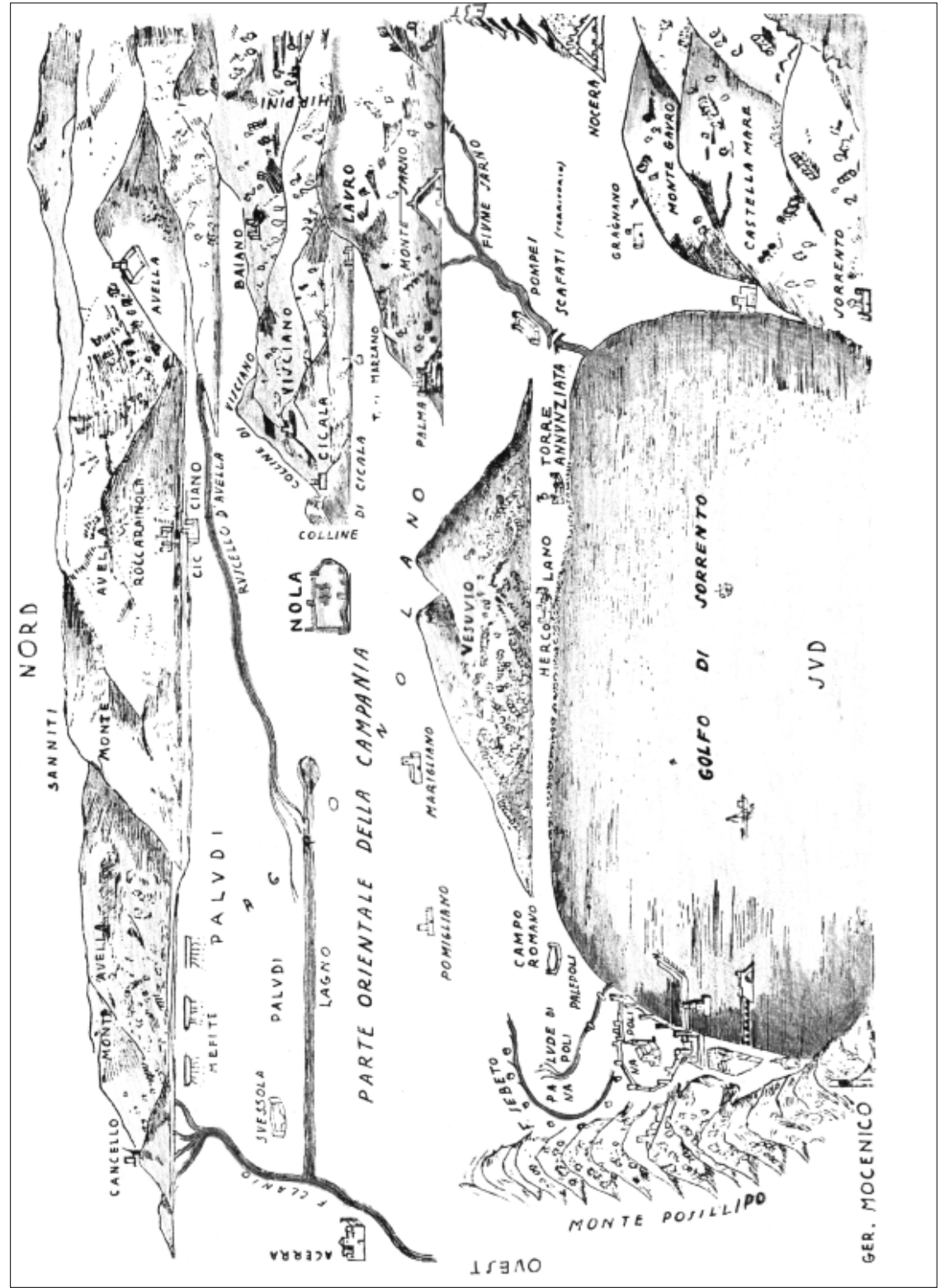

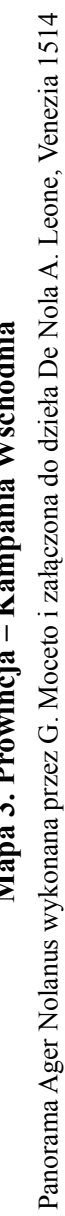




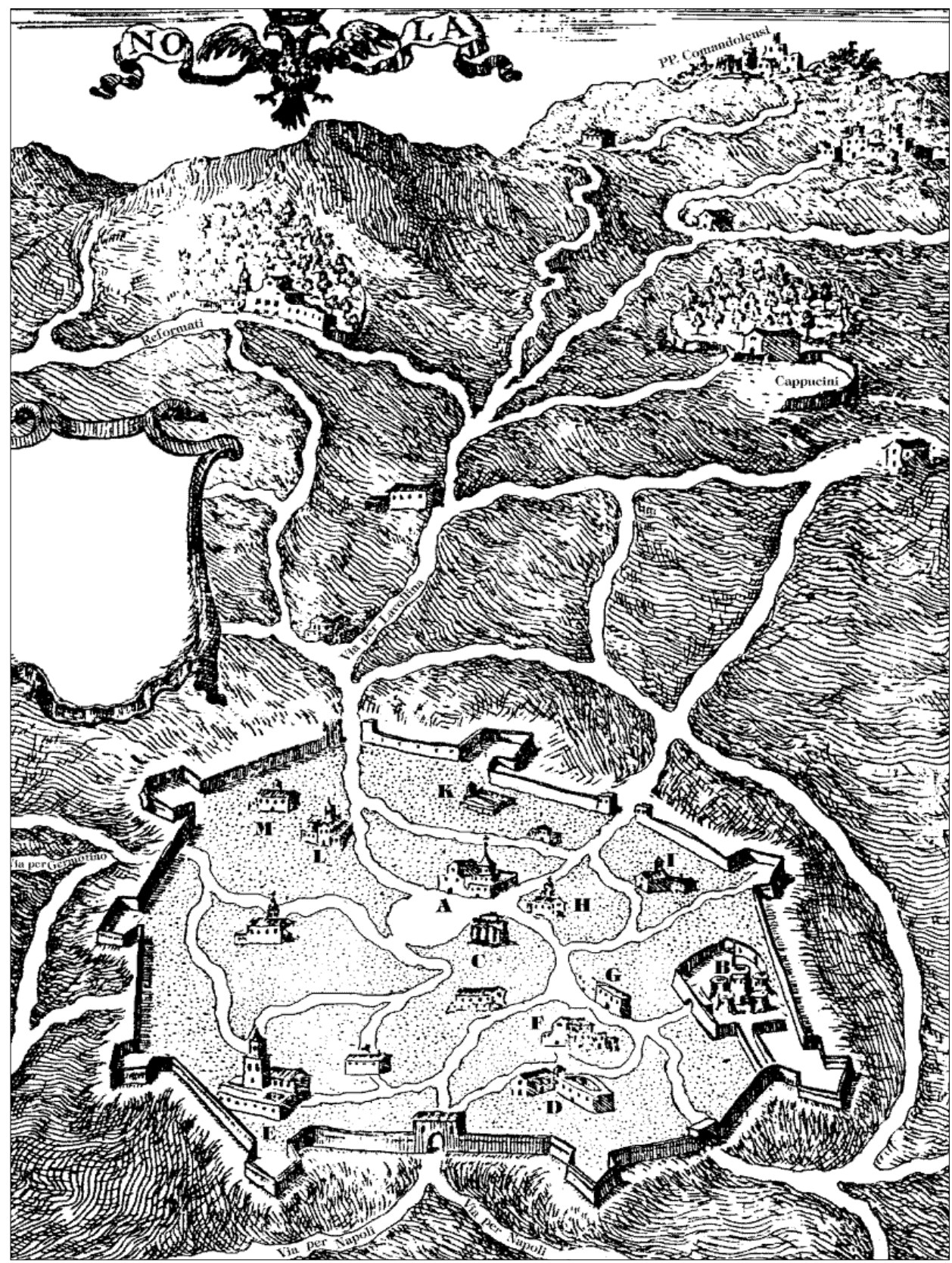

A - Cattedrale, B - Castello, C - il Seggio, D - Collegio de PP. Gesuiti, E - Francescani, F - Carmelitani, G - Orfanelli, H - Augustiniani, I - La Place, K - S. Spirito Mon., L - La Douana, M - S. Antonio Abbate

Mapa 4. Miasto Nola i okolice w XVI wieku

(Giovanni Battista Pacichelli, Il Regno di Napoli In Prospettiva - divisio in dodeci provincie, cz. 1, Napoli 1703, s. 114) 